\title{
Evaluation of heat stress effects on cellular and transcriptional adaptation of bovine granulosa cells
}

\author{
Adnan Khan ${ }^{1}$, Jinhuan Dou', Yachun Wang ${ }^{*}$, Xiaolong Jiang ${ }^{2}$, Muhammad Zahoor Khan ${ }^{1}$, Hanpeng Luo ${ }^{1}$, \\ Tahir Usman ${ }^{3}$ and Huabin Zhu
}

\begin{abstract}
Background: Heat stress is known to affect follicular dynamics, oocyte maturation, and fertilization by impairing steroidogenic ability and viability of bovine granulosa cell (bGCs). The present study explored the physiological and molecular response of bGCs to different heat stress intensities in-vitro. We exposed the primary bGCs to heat stress (HS) at $39^{\circ} \mathrm{C}, 40^{\circ} \mathrm{C}$ and $41^{\circ} \mathrm{C}$ along with control samples $\left(38^{\circ} \mathrm{C}\right)$ for $2 \mathrm{~h}$. To evaluate the impact of heat stress on bGCs, several in vitro cellular parameters including cell apoptosis, intracellular reactive oxygen species (ROS) accumulation and HSP70 kinetics were assessed by flow cytometry, florescence microscopy and western blot, respectively. Furthermore, the ELISA was performed to confirm the $17 \beta$-estradiol $\left(E_{2}\right)$ and progesterone $\left(P_{4}\right)$ levels. In addition, the RNA sequencing (RNA-Seq) method was used to get the molecular based response of bGCs to different heat treatments.

Results: Our findings revealed that the HS significantly decreased the cell viability, $E_{2}$ and $P_{4}$ levels in bGCs, whereas, increased the cellular apoptosis and ROS. Moreover, the RNA-Seq experiments showed that all the treatments $\left(39^{\circ} \mathrm{C}, 40^{\circ} \mathrm{C}\right.$ and $\left.41^{\circ} \mathrm{C}\right)$ significantly regulated many differentially expressed genes (DEGs) i.e. BCL2L1, STAR, CYP11A1, CASP3, SOD2, HSPA13, and MAPK8IP1 and pathways associated with heat stress, apoptosis, steroidogenesis, and oxidative stress. Conclusively, our data demonstrated that the impact of $40^{\circ} \mathrm{C}$ treatment was comparatively detrimental for cell viability, apoptosis and ROS accumulation. Notably, a similar trend of gene expression was reported by RT-qPCR for RNA-seq data.
\end{abstract}

Conclusions: Our study presented a worthy strategy for the first time to characterize the cellular and transcriptomic adaptation of bGCs to heat stress $\left(39,40\right.$ and $41^{\circ} \mathrm{C}$ ) in-vitro. The results infer that these genes and pathways reported in present study could be useful candidates/indicators for heat stress research in dairy cattle. Moreover, the established model of bGCs to heat stress in the current study provides an appropriate platform to understand the mechanism of how heat-stressed bGCs can affect the quality of oocytes and developing embryo.

Keywords: Bovine granulosa cells, Differentially expressed genes, Follicles, Heat stress, RNA-Seq

\section{Background}

Mammalian ovarian follicle, consisting of an oocyte that undergoes series of biological events including ovulation, fertilization, and formation of an embryo is surrounded

\footnotetext{
* Correspondence: wangyachun@cau.edu.cn

${ }^{1}$ Key Laboratory of Animal Genetics, Breeding, and Reproduction, MARA; National Engineering Laboratory for Animal Breeding, College of Animal Science and Technology, China Agricultural University, Beijing 100193, People's Republic of China

Full list of author information is available at the end of the article
}

by granulosa and theca cells producing signals and hormones to enable the oocyte to develop [1]. During follicle development, granulosa cells (GCs) replicate, secrete hormones, and provide a critical microenvironment for follicular growth [2]. Proliferation and differentiation of GCs is essential for normal follicular growth, development of oocyte, ovulation, and luteinization [3, 4].

Heat stress is one of the environmental factors that have harmful effects on the function of ovaries [5] and 
subsequently decreases the developmental ability of oocytes to be fertilized and further develop the competent embryo [6]. It significantly reduced the production of estradiol, and stenedione synthesis by theca cells [7], inhibited proliferation and induced apoptosis in swine granulosa cells [8]. In support of this, heat stress during in vitro fertilization increased polyspermy and decreased fertilization success by disrupting the antipolyspermy system in oocytes [9], suggesting that heat stress during fertilization mainly affects the oocyte and its developmental competence. Mammalian cells are known to respond to a wide range of environmental stressors in a variety of ways including; heat shock response protein expression [10], unfolded protein response (UPR) [11] and oxidative stress response [12] to support cell survival under suboptimal conditions. Cells may use constitutive induced heat shock proteins (HSPs), molecular chaperones in response to heat stress that facilitate the synthesis, folding, assembly, and transportation of stressdenatured proteins [13]. Heat shock $70 \mathrm{kDa}$ protein (HSP70) is a major stress protein induced in mouse GCs by high temperature [9]. Increasing evidence suggests that heat stress induces intracellular ROS concentration [14], resulting in apoptosis of granulosa cells in the mouse [15]. In addition, ROS may subsequently alter the development of bovine embryos during in-vitro oocyte maturation [16].

RNA sequencing (RNA-Seq) has emerged as an innovative method for both mapping and quantifying transcriptome signatures associated with traits [17]. One of the most biologically relevant applications of RNA-Seq is the comparison of mRNA transcriptome across samples from diseased vs. normal individuals, or other specific experimental conditions [18]. The usage of highthroughput RNA sequencing technology has become a powerful tool and a standard method for the measurement and comparison of gene expression levels in a myriad of species and conditions [19]. Therefore, in our study, we employed RNA-Seq to characterize the complete transcriptome of bGC and facilitate the discovery of differentially expressed genes as well as novel genes and pathways under heat stress.

This study was conducted in Beijing, China. Temperature levels were selected for the experiment to treat the granulosa cells, isolated from the ovaries of cattle that were well adapted to the local environment. For instance, we attempted to select experimental temperature levels that were relevant to the physiological body temperatures of cattle under HS in Beijing. During the summer, we collected the data from many dairy farms in Beijing, showing how environmental temperature-humidity index (THI) can affect rectal body temperature (RT). We found that in summer, body temperature may rise to $41{ }^{\circ} \mathrm{C}$ (Fig. 1). Therefore, we
THI vs RT during summer in Beijing

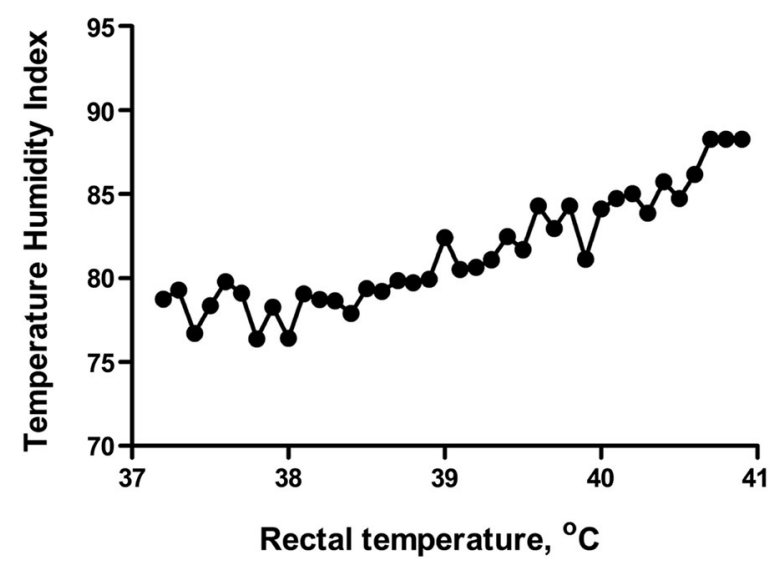

Fig. 1 Temperature humidity index can affect body rectal temperature: Evaluation of change in rectal body temperature (RT) with increase in percent temperature humidity index (\%THI)

evaluated the effects of the four temperature levels [38 (control), 39, 40, and $41^{\circ} \mathrm{C}$ ] on the physiological traits and transcriptomic gene expression profile in bGCs.

Moreover, while much is now known about the effects of various factors on normal granulosa cells [14, 20], to the best of our understanding, no attempt has been taken so far to propose a molecular mechanism or explore gene interactions and molecular pathways related to heat stress response in bGCs at different heat intensities. We hypothesize that, relative to control, bGCs exposed to heat stress will experience alterations both in physiological traits and expression of key genes and pathways required for normal cellular functions. Therefore, the present study was aimed to explore cellular adaptation, generate global gene expression profile of bovine granulosa cells under normal and heat-stressed state and identify molecular pathways significantly regulated in heat-stressed bGCs.

\section{Methods}

Collection of bovine ovaries and granulosa cells isolation Ovaries from dairy cattle were collected from a local abattoir and transported to the laboratory in thermally insulated bottles containing sterile physiological saline with $100 \mathrm{U} / \mathrm{mL}$ Penicillin and $0.1 \mathrm{mg} / \mathrm{mL}$ Streptomycin, at $28-30{ }^{\circ} \mathrm{C}$ within $2 \mathrm{~h}$ of harvesting. After washing with warm $0.9 \% \mathrm{NaCl}$ solution three times and rinsing in $70 \%$ warm ethanol for $30 \mathrm{~s}$, ovaries were washed thrice with warm Dulbecco's Phosphate-Buffered Saline (DPBS). For isolation of BGCs, small healthy follicles (with a diameter of 2-6 mm) were selected using an 18-gauge sterile needle (B-Braun, Germany) and transferred into $15 \mathrm{~mL}$ conical centrifuge tubes (Corning, NY, USA). The follicular fluid containing cumulus-oocyte complexes 
(COCs) and granulosa cells was filtered using a filter with a diameter of $70 \mu \mathrm{m}$ leaving COCs on the filter. The filtrate with granulosa cells was carefully transferred into $15 \mathrm{~mL}$ conical centrifuge tubes, centrifuged at $1500 \times g$ for $5 \mathrm{~min}$. The supernatant of the follicular fluid was discarded by aspiration, and granulosa cells were washed thrice in phosphate-buffered saline (PBS), $\mathrm{pH}$ 7.4. The GCs were then resuspended in DMEM/F-12 (Gibco, Life Technologies Inc., Grand Island, NY, USA) supplemented with $1 \%$ penicillin-streptomycin and $10 \%$ fetal bovine serum (FBS, Gibco, Life Technologies Inc., Grand Island, NY, USA).

\section{Granulosa cell culture and heat treatment} Granulosa cells $\left(6 \times 10^{6}\right.$ cells per well) were precultured in a 6-well plate (Starlab, Hamburg, Germany) with 2 $\mathrm{mL}$ of DMEM/F-12 (Gibco, Life Technologies Inc., Grand Island, NY, USA) culturing media supplemented with $1 \%$ penicillin-streptomycin and 10\% FBS (Gibco, Life Technologies Inc., Grand Island, NY, USA) at $38^{\circ} \mathrm{C}$ (optimal and physiologically relevant temperature for culturing mammalian ovarian cells) under $5 \% \mathrm{CO}_{2}$ in humidified air.

After $48 \mathrm{~h}$ of preculture, cells were attached to the bottom of the wells with the confluence of more than $80 \%$; the medium was replaced with the fresh medium of the same composition. GCs were then cultured at temperatures control group $\left(38^{\circ} \mathrm{C}\right)$, or heat treatment groups $\left(39,40\right.$ and $\left.41^{\circ} \mathrm{C}\right)$ for $2 \mathrm{~h}$, and then the cells were cultured at $38^{\circ} \mathrm{C}$ for $12 \mathrm{~h}$. The cells and culture media were collected for further analysis immediately after the culture. Following heat treatments, cultured GCs were harvested using $0.25 \%$ trypsin-EDTA (Sigma-Aldrich Chemie, Taufkirchen, Germany).

\section{Western blot analysis of HSP70}

Western blot analysis was used in all samples to determine the expression of inducible HSP7O under heat stress. Granulosa cells from each group were washed thrice with 0.1\% PVA/PBS, lysed in RIPA lysis buffer (Beyotime, Shanghai, China) containing protease inhibitors. Total protein concentration was measured with Protein Assay (Bio-Rad, 500-0002) and a spectrophotometer at $595 \mathrm{~nm}$ (Beckman, DU 530). Proteins were denatured at $100^{\circ} \mathrm{C}$ for $10 \mathrm{~min}$, separated by SDS-PAGE (12\% acrylamide gel containing $0.1 \%$ SDS) and transferred onto a nitrocellulose membrane (BioTraceNT, Pall Corp., Port Washington, NY, USA). Membranes were then blocked with $5 \%(\mathrm{w} / \mathrm{v})$ skim milk in Trisbuffered saline (TBS) containing 0.1\% Tween 20 (TBST) at $37^{\circ} \mathrm{C}$ for $1 \mathrm{~h}$. The membranes were incubated overnight at $4{ }^{\circ} \mathrm{C}$ with primary antibodies against HSP70 and $\beta$-actin after three washes in TBST. All primary antibodies were purchased from Cell Signaling Technology
(Beverly, MA, USA), and diluted to a concentration of 1 : 1000. After washing in TBST thrice, the membranes were incubated at room temperature for $1 \mathrm{~h}$ with horseradish peroxidase (HRP)-conjugated secondary antibody (Zhongshan Biotechnology, Beijing, China). Based on the manufacturer's instructions, the protein bands were detected using enhanced chemiluminescence (ECL) detection kit (Tanon, Shanghai, China) and analyzed by densitometry using Image J 1.44p software. The final data exported from Image J was analyzed in Microsoft Excel. Western blot in triplicate was performed for all samples.

\section{Determination of estradiol and progesterone by ELISA}

All of the culture media was collected from controlled and heat treated groups and then estimated the levels of $\mathrm{P}_{4}$ and $\mathrm{E}_{2}$. The concentrations of $\mathrm{P}_{4}$ and $\mathrm{E}_{2}$ were determined using an estrogen and progesterone enzymelinked immunosorbent (ELISA) kits (ENZO life sciences, Germany) according to the manufacturer's instruction.

\section{Determination of intracellular ROS production}

About $2 \times 10^{4}$ granulosa cells were cultured in 96-well plates. After growing to a confluence of more than $80 \%$, GCs were incubated at $38,39,40$ and $41{ }^{\circ} \mathrm{C}$ for $2 \mathrm{~h}$. Following incubation, cells were stained with $10 \mu \mathrm{mol} / \mathrm{L}$ H2DCFDA fluorescent probe (6-carboxy- $2^{\prime}, 7^{\prime}$-dichlorodihydrofluorescein diacetate) (Invitrogen, Carlsbad, CA, USA) for $30 \mathrm{~min}$ at $38^{\circ} \mathrm{C}$ in the dark. GCs samples were then washed once in $0.1 \%$ PVA/DPBS, and the images were captured immediately under a fluorescence microscope (Olympus, Tokyo, Japan) equipped with a CoolSNAP HQ CCD camera (Photometrics/Roper Scientific, Inc., Tucson, AZ, USA). Image J 1.44p software was used to analyze the fluorescence intensity.

\section{Estimation of granulosa cells apoptosis}

Bovine GCs were harvested by enzymatic digestion using trypsin and washed three times with preheated PBS. Using the FITC-Annexin V/dead cell apoptosis kit (Life Technologies Inc., Grand Island, NY, USA), APC annexin V/PI double staining was performed to evaluate the granulosa cell apoptosis according to the manufacturer's instructions before being analyzed by flow cytometry. The data were analyzed by Flowjo software (version Win64-10.4.0).

\section{Estimation of cell viability}

Cultured and heat treated GCs were trypsinized, collected, and washed with warm PBS. The GCs were then passing through APC annexin V/PI double staining by utilizing the FITC-Annexin V/dead cell apoptosis kit (Life Technologies Inc., Grand Island, NY, USA) to assess the cell viability and apoptosis. Samples were 
washed with $1 \times$ annexin-binding buffer for $5 \mathrm{~min}$ in accordance with the manufacturer's instructions and incubated in $490 \mu \mathrm{L} 1 \times$ annexin-binding buffer supplemented with $10 \mu \mathrm{L}$ annexin $\mathrm{V}$ conjugate at room temperature in the dark for $15 \mathrm{~min}$. A laser-scanning confocal microscope (TCS SP8, Leica, Germany) was used to determine the number of early apoptotic and dead cells.

\section{RNA extraction for RNA-Seq}

The RNA was isolated from bovine granulosa cells using RNA kit (Tiangen, Beijing, China) according to the manufacturer's instructions. RNA samples were treated with RNase free DNase I to avoid DNA contamination. RNA degradation and contamination were detected by $1 \%$ agarose gels. The RNA concentration was assessed using NanoPhotometer spectrophotometer (Implen, CA, USA). The extracted RNA was stored at $-80{ }^{\circ} \mathrm{C}$ and all 12 samples (three from each group) were sent to the company (Gene Denovo Biotechnology Co. Guangzhou, China) for RNA-Seq analysis.

\section{Library construction for RNA-Seq}

Three samples from each group were selected for library preparation. For the RNA sample preparations, A total amount of $2 \mu \mathrm{g}$ RNA per sample was used as input material. Using NEBNext ${ }^{\circ}$ Ultra $^{\mathrm{Tw}}$ RNA Library Prep Kit for Illumina $^{\circ}$ (\#E7530L, NEB, USA),sequencing libraries were generated following the manufacturer's recommendations and index codes were added to assign sequences to each sample. Briefly, using Oligo (dT) magnetic beads mRNA was purified from total RNA. Fragmentation was done in NEBNext First-Strand Synthesis Reaction Buffer $(5 \times)$ using divalent cations at high temperature. First strand cDNA was synthesized using random hexamer primer, and RNase $H$. DNA polymerase I, RNase $H$, dNTP, and buffer were used to synthesize second-strand cDNA. Then the fragments cDNA were purified with QiaQuick PCR extraction kit, end repaired, poly(A) added, and ligated to Illumina sequencing adapters. The ligation products were size selected by agarose gel electrophoresis, PCR amplified and sequenced by Gene Denovo Biotechnology Co. (Guangzhou, China) using Illumina $\mathrm{HiSeq}^{\mathrm{mm}} 2500$ and generated 150 bp paired-end reads.

\section{Bioinformatics and statistical analysis of RNA-Seq}

Raw reads generated by Illumina Hiseq ${ }^{\mathrm{Tx}} 2500$ were initially processed to get clean reads through the following three steps. i) Removing reads with adaptors contamination; ii) Discarding reads containing more than $10 \%$ of unknown nucleotides $(\mathrm{N})$; iii) Removing low quality reads containing more than $50 \%$ of low quality (Q-value $\leq 20$ ) bases using Next Generation Sequencing (NGS) Quality Control Toolkit version 2.3.3. The filtered reads of each sample was individually mapped to 48370 reference mRNAs from the Bos taurus reference genome (UMD3.1) obtained from Ensembl (ftp: //ftp. Ensembl. org/pub/release-73/fasta/bos_taurus/dna/) HISAT2 software version 2.0.1 (http://ccb.jhu.edu/software/hisat2). The transcripts were then assembled and quantified using StringTie software version 1.2.2 (http://ccb.jhu. edu/software/stringtie). Using StringTie, transcript files generated were added to a single-merged transcriptome annotation to merge transcripts from different replicas of a group into a comprehensive set of transcripts, and then merge the transcripts from multiple groups into a finally a comprehensive set of transcripts for further downstream differential expression analysis. Differentially expressed genes (DEGs) and transcripts were identified among different sample groups using Ballgown. Ballgown was used as a pipeline package in the $\mathrm{R}$ programming language version 3.2.2 (https://www.r-project. org) and the Bioconductor software was used for plotting raw data, normalization and downstream statistical modeling. Gene expression values were calculated by counting the number of fragments per kilobase of transcript per million mapped fragments (FPKM), and Cuffdiff was applied to measure significant differences among the four groups. The result was sorted in Microsoft Excel. DEGs were subjected to Gene Ontology (GO) enrichment and Kyoto Encyclopedia of genes and genomes (KEGG) pathway analyses using the Molecule Annotation System http://david.abcc.ncifcrf.gov/) [21]. Using STRING software (version 10), a network was constructed with the genes involved in the significant pathways in order to generate a protein-protein interaction (PPI) network and to predict physical/functional PPIs. The heat map was constructed using ggplot two packages in R (version 3.2).

\section{Quantitative reverse transcription PCR (RT-qPCR) validation for RNA-Seq analysis}

RT-qPCR was conducted to confirm the results of RNASeq. Total RNA was extracted from three biological replicates of control and heat-treated granulosa cells as described above and was reverse transcribed using first strand cDNA synthesis Kit (Thermo Fisher Scientific, Germany) with oligo (dT) 18 primers according to the manufacturer protocols. The expression levels were checked for 15 genes. Primer3 web version 4.0.0 (http:// bioinfo.ut.ee/primer3/) and Primer blast (http://www. ncbi.nlm.nih.gov/tools/primer-blast/) were used for designing gene-specific primers and are shown in (Additional file 5). The RT-qPCR was conducted using iTaq $^{\text {Tn }}$ Universal SYBR ${ }^{\circ}$ Green Supermix (Bio-Rad Laboratories $\mathrm{GmbH}$, Germany) in Applied Biosystem ${ }^{\circ}$ StepOnePlus $^{\text {ma }}$ (Applied biosystems, CA, USA). A reaction volume of $20 \mu \mathrm{L}$ with $7.4 \mu \mathrm{L}$ of $\mathrm{ddH}_{2} \mathrm{O}, 0.3 \mu \mathrm{L}$ of forwarding primer, $0.3 \mu \mathrm{L}$ of reverse primer, $10 \mu \mathrm{L}$ of $1 \times$ 
SYBR Green master mix (Bio-Rad Laboratories $\mathrm{GmbH}$, Germany), and $2 \mu \mathrm{L}$ of cDNA template was used. The Light Cycler 480 instrument (Roche, Germany) was used for performing qPCR. The second derivative maximum method was employed for data acquiring and subjected for further analysis. Using GAPDH as a reference gene, the $2^{-\Delta \Delta C T}$ method was used to calculate gene expression levels, [21].

\section{Statistical analysis}

Data are expressed as mean values \pm SEM. Statistical analysis was carried out using SPSS 16.0. The difference between control and heat-treated groups for cell apoptosis, cell viability, steroidogenesis, ROS accumulation as well as the RT-qPCR results were analyzed using Oneway ANOVA followed by multiple comparisons post hoc test. Differences were considered to be statistically significant at $P<0.05$.

\section{Results}

Heat stress induces HSP70 expression in bovine granulosa cells

Bovine granulosa cells were heat treated at different temperature levels (Control, 39, 40 and $41^{\circ} \mathrm{C}$ ) for $2 \mathrm{~h}$ duration to investigate the effect of heat stress on the expression level of HSP70 in bGCs. We performed western blot and RT-qPCR to check relative abundance of HSP7O both on mRNA and protein level. Our results showed that the expression of HSP7O between control and heat stressed group $\left(39^{\circ} \mathrm{C}\right)$ was not significantly different. However, the expression of HSP70 was significantly up-regulated in bGCs under heat stress at $40{ }^{\circ} \mathrm{C}$ and $41{ }^{\circ} \mathrm{C}$ post-treatment (Fig. 2a, b).

\section{Heat stress exposure elevates bovine granulosa cell apoptosis}

The bGCs apoptotic rate was estimated by flow cytometry (FCM) and fluorescence microscopy. It was found that the apoptotic rate (early + late apoptosis) of the GCs was significantly higher $(P<0.05)$ in the heattreated groups (Fig. 3a, b). During cell culture, bGCs were exposed to heat stress for $2 \mathrm{~h}$ with a range of temperatures (Control, 39, 40 and $41^{\circ} \mathrm{C}$ ). Following heat stress exposure, the cell apoptotic rate was increased in temperature-dependent fashion. As shown in Fig. 3a, b, the apoptotic rate $(46 \%)$ of bGCs was significantly $(P<$ $0.05)$ higher at $40^{\circ} \mathrm{C}$ than other treatments. However, with respect to $40^{\circ} \mathrm{C}$, the apoptotic rate of GCs was lower at $41{ }^{\circ} \mathrm{C}(35.4 \%)$. Heat treatment of $39^{\circ} \mathrm{C}$ did not change apoptotic rate $(9 \%)$ significantly than control group (3.96\%). Similar effect of heat stress was noticed for cell viability. Significantly $(P<0.05)$ lower cell

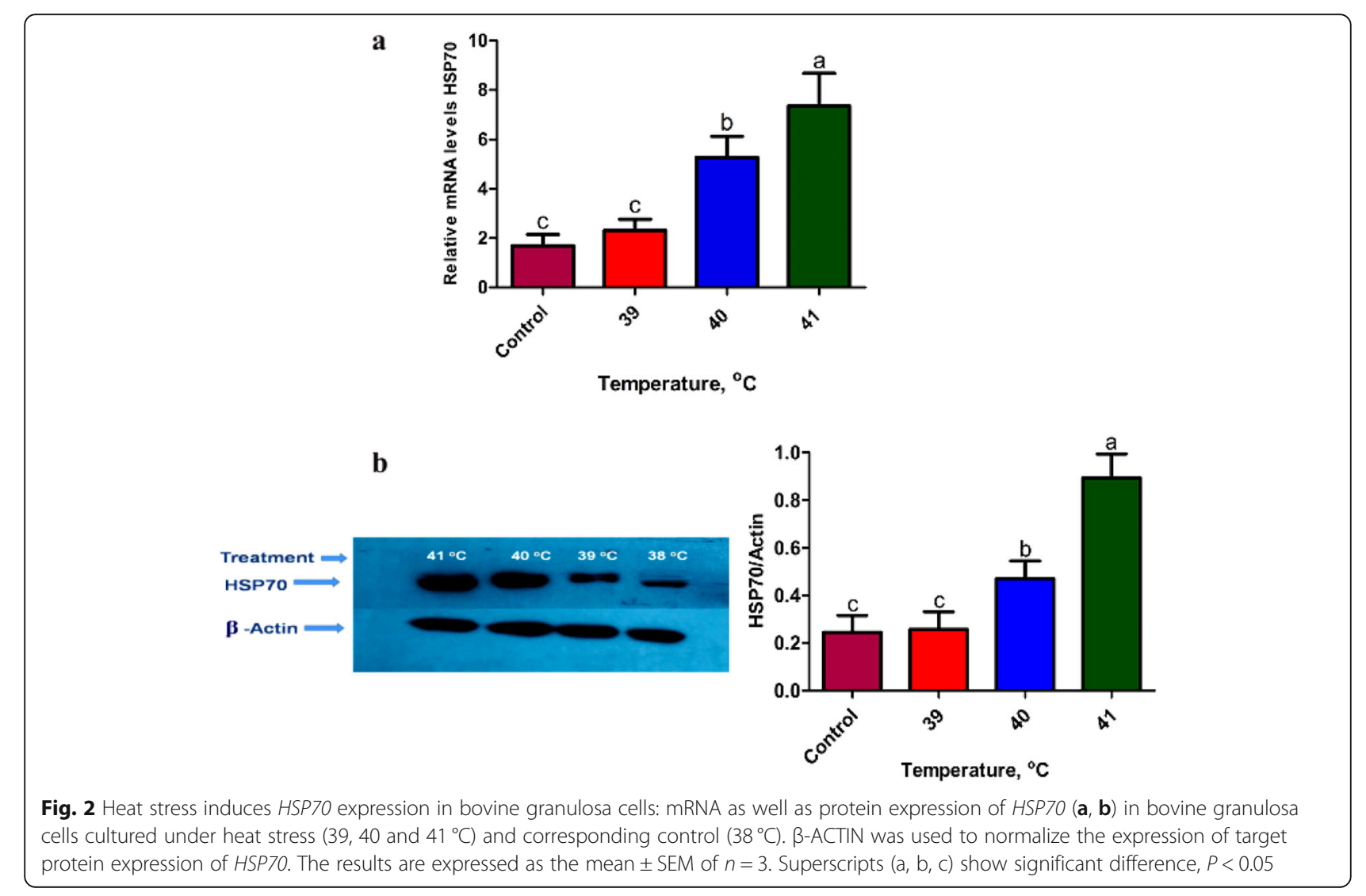




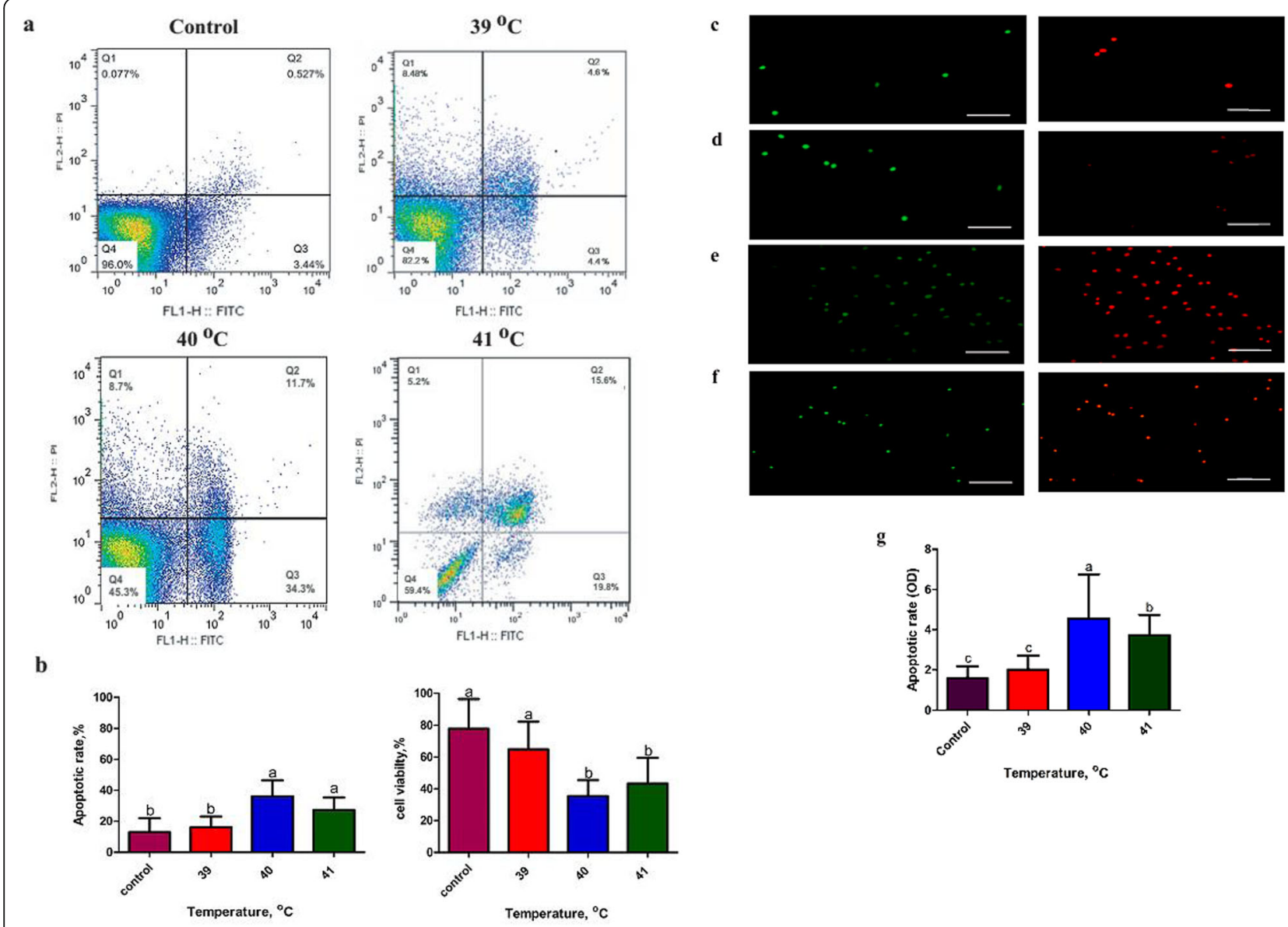

Fig. 3 Heat stress exposure elevates bovine granulosa cell apoptosis and decreases viability: Flow cytometric analysis of bovine granulosa cells (bGCs) cultured under heat stress $\left(39,40\right.$ and $\left.41^{\circ} \mathrm{C}\right)$ and corresponding control $\left(38^{\circ} \mathrm{C}\right)(\mathbf{a}, \mathbf{b})$. The analyzed cell counts for apoptosis and viability are indicated on the $Y$-axis and the temperature treatments are indicated on the $X$-axis. Data shown as means $\pm S E M, n=3, P<0.05$. Fluorescent photomicrographs of bovine granulosa cells (bGCs) stained with 2',7'-dichlorofluorescin diacetate $\left(\mathrm{H}_{2} \mathrm{DCFDA}\right)$ were shown control $\left(38^{\circ} \mathrm{C}\right)(\mathbf{c})$ and heat stress $(39,40$ and $\left.41^{\circ} \mathbf{C}\right)(\mathbf{d}, \mathbf{e}, \mathbf{f}$, respectively). The images shown are representative of the three independent image acquisitions. $\mathbf{g}$ Quantitative analysis of relative fluorescence emission. Values are expressed as mean \pm SEM of $n=3$. Superscripts $(a, b, c)$ show significant difference, $P<0.05$

viability was found at $40{ }^{\circ} \mathrm{C}(45.3 \%)$ as compared to control $(96 \%)$ and $39^{\circ} \mathrm{C}(82.2 \%)$. No significant difference were noticed between $40^{\circ} \mathrm{C}(45.3 \%)$ and $41{ }^{\circ} \mathrm{C}(59.4 .3 \%)$ as shown in Fig. 3a, b. Fluorescence microscopy was also conducted to estimate the apoptotic rate and viability of $\mathrm{GCs}$ and found that the relative fluorescence emissions were higher when GCs were exposed to $40^{\circ} \mathrm{C}$ than the control group. However, the $39^{\circ} \mathrm{C}$ treatment group did not show any significant $(P<0.05)$ difference with the control group. Likewise, fluorescence microscopy showed that after $40^{\circ} \mathrm{C}$, the apoptotic rate decreased significantly $(P<0.05)$ in the heat stress group at $41{ }^{\circ} \mathrm{C}$ (Fig. 3c, d, e, f, g).

\section{Effects of heat stress on $E_{2}$ and $P_{4}$ secretion by bovine granulosa cells}

The concentration of $\mathrm{E}_{2}$ (Fig. 4a) in the heat-treated groups $\left(40\right.$ and $\left.41^{\circ} \mathrm{C}\right)$ was significantly lower $(P<0.05)$ than the control and $39^{\circ} \mathrm{C}$ group in the culture media. However, heat treated group at $39^{\circ} \mathrm{C}$ did not show a significant difference with the control group. Furthermore, a significant $(P<0.05)$ difference was noticed between treatment groups of 40 and $41^{\circ} \mathrm{C}$. Similar secretion pattern was also observed for $\mathrm{P}_{4}$ with the significant difference $(P<0.05)$ between control and heat-treated groups (40 and $41^{\circ} \mathrm{C}$ ) (Fig. 4b). However, no significant difference was noticed between 40 and $41{ }^{\circ} \mathrm{C}$ treated groups.

\section{Heat stress enhanced intracellular ROS accumulation in bovine granulosa cells}

Following exposure to heat stress at $40^{\circ} \mathrm{C}$, an increasing level of intracellular ROS accumulation was observed in granulosa cells compared to other cell cultured groups (Fig. 5c). However, there were no significant differences in ROS accumulation at $39^{\circ} \mathrm{C}$ (Fig. 5a, b, e). Furthermore, the relative fluorescence emissions were 
$\mathbf{a}$

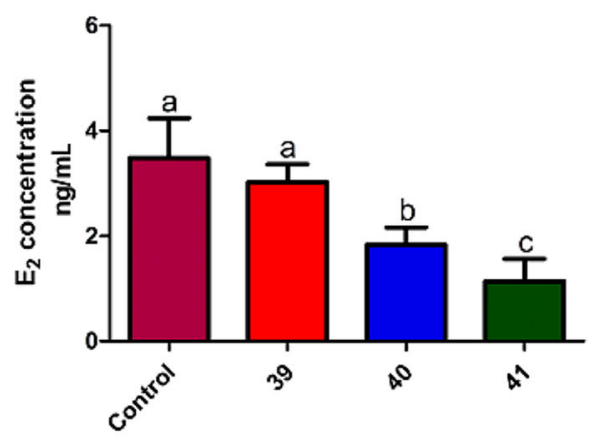

Temperature, ${ }^{\circ} \mathrm{C}$ b

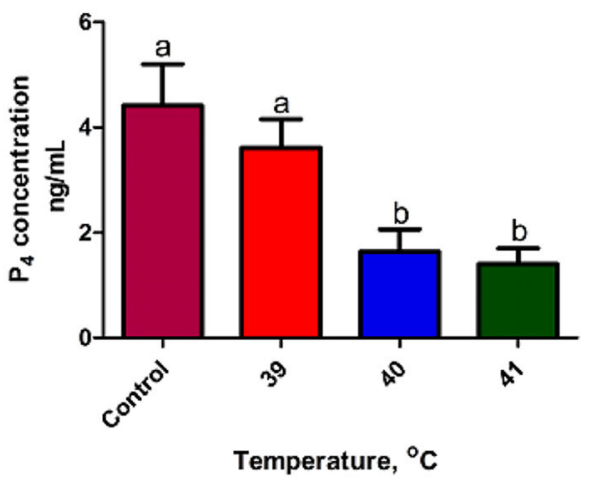

Fig. 4 Effects of heat stress on $E_{2}$ and $P_{4}$ secretion by bovine granulosa cells: Concentration of $E_{2}(\mathbf{a})$ and $P_{4}$ (b) in culture media of bovine granulosa cells (bGCs) cultured under heat stress $\left(39,40\right.$ and $\left.41^{\circ} \mathrm{C}\right)$ and corresponding control $\left(38^{\circ} \mathrm{C}\right)$. Values are expressed as mean $\pm \mathrm{SEM}$ of $n=$ 3. Superscripts $(a, b, c)$ show significant difference, $P<0.05$

significantly higher $(P<0.05)$ when bGCs were exposed to $41^{\circ} \mathrm{C}$ than the control group but lower than $40{ }^{\circ} \mathrm{C}$ (Fig. 5d).

RNA sequencing data analysis for identifying differentially expressed genes among three groups (control vs. $39^{\circ} \mathrm{C}$, control vs. $40^{\circ} \mathrm{C}$ and control vs. $41^{\circ} \mathrm{C}$ )

In this study, an attempt was made to obtain a global picture of the in-vitro heat stress response by investigating the transcriptome profile of bGCs. Differentially expressed genes (DEGs) of bGCs were identified via RNA-Seq to analyze genome-wide transcriptional expression differences among the three groups. Under the criteria of |fold change $(|\mathrm{FC}|)>1.5$ and $P<0.05,142$ DEGs, including 88 (61.9\%) up-regulated and 54 (38\%) down-regulated were identified by comparing control versus (vs.) $39^{\circ} \mathrm{C}$ group. Similarly, for Control vs. $40{ }^{\circ} \mathrm{C}$, a total of 321 DEGs with 153 (47.6\%) up and 169 (52.6\%) down-regulated were reported. During the comparison of control versus $41{ }^{\circ} \mathrm{C}, 294$ significantly DEGs were detected containing 157 (53.4\%) up and 137 (46.5\%) down-regulated genes (Additional file 1, Table 1, Fig. 6a). Results revealed the highest number of DEGs in Control vs. $40^{\circ} \mathrm{C}$, whereas the least DEG number was detected in control vs. $39^{\circ} \mathrm{C}$ group. These results indicate a strong inducement of genes in $40^{\circ} \mathrm{C}$ bGCs cultured group.

Heat stress resulted in the activation of differentially expressed heat shock factors, apoptotic, steroidogenic and oxidative stress-related genes

Among the several hundred genes induced or repressed as a result of in-vitro heat stress, an effort was made to filter out genes related to; heat shock protein family, apoptosis; steroidogenesis and oxidative stress (Table 2). A heatmap and hierarchical clustering of the top 45

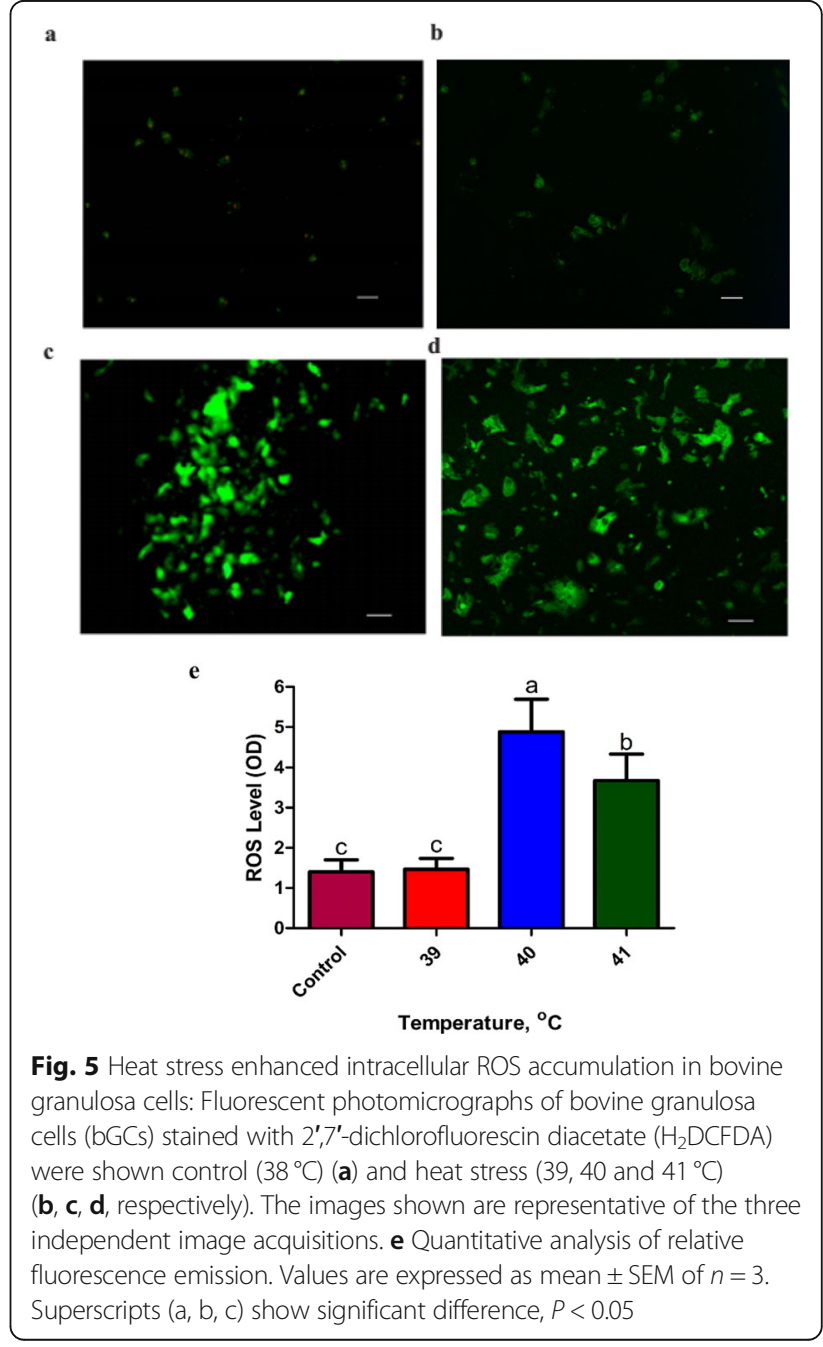


Table 1 Number of differentially expressed genes (DEGs) disclosed in three comparisons of bovine granulosa cells (bGCs) after heat stress

\begin{tabular}{lllll}
\hline Groups & Total genes & Up regulated & Down regulated & Criteria \\
\hline Control vs. $39^{\circ} \mathrm{C}$ & 142 & 88 & 54 & $\mathrm{FC}>1.5, P<0.05$ \\
Control vs. $40^{\circ} \mathrm{C}$ & 321 & 153 & 169 & $\mathrm{FC}>1.5, P<0.05$ \\
Control vs. $41^{\circ} \mathrm{C}$ & 294 & 157 & 137 & $\mathrm{FC}>1.5, P<0.05$ \\
\hline
\end{tabular}

significant $(P<0.05)$ differentially expressed genes with $|\mathrm{FC}|>1.5$ and $P<0.05$ demonstrates the relatedness of samples, as shown in Fig. 6c.

\section{Pathway analysis of differentially expressed genes in response to heat stress}

For an enhanced understanding of signaling pathways regulated by the heat treatments, the identified DEGs in the three comparisons were subjected to pathway analysis using KEGG.

\section{Control vs. $39^{\circ} \mathrm{C}$ cultured group}

A total of 25 canonical pathways enriched by genes differentially expressed in granulosa cells in this comparison (Additional file 2), of which 18 were significantly $(P<0.05)$ regulated (Fig. 7a, Table 3$)$ while the rest of the eight did not meet the criteria for significance $(P<0.05)$. The number of up and down-regulated DEGs involved in these 18 KEGG pathways are presented in Fig. 7a. Furthermore, among significantly regulated pathways, 15 were directly related to the qualitative traits of bGCs under heat stress and the genes distributed in each pathway are enlisted in (Additional file 2).

\section{Control vs. $40^{\circ} \mathrm{C}$ cultured group}

Total of 18 canonical pathways was enriched in response to heat stress; out of them, 12 were significantly $(P<$ 0.05 ) regulated (Additional file 2, Table 3 ). The 13 pathways which have key roles in the apoptosis, oxidative stress, antioxidant and steroidogenesis regulation of the bGCs were selected and shown in Fig.7b based on up and down-regulated genes. Between the comparisons of Control vs. $39^{\circ} \mathrm{C}$ and Control vs. $40^{\circ} \mathrm{C}$, seven commonly shared pathways were reported. Furthermore, our findings concealed that most of the DEGs among these pathways were up-regulated (Additional file 2). With the increase in heat stress in Control vs. $40^{\circ} \mathrm{C}$ comparison. Glutathione metabolism pathways were up-regulated to combat stress by regulating antioxidant genes (SOD1, SOD2, etc.) (Fig. 7b).

\section{Control vs. $41{ }^{\circ} \mathrm{C}$ cultured group}

Out of 28 canonical KEGG enriched pathways in control vs. $41{ }^{\circ} \mathrm{C}$ comparison, 23 reached a significant level $(P<0.05)$ and are shown based on up and down-regulated genes (Additional file 2, Fig. 7c, Table 3). Furthermore, 14 pathways were involved in the regulation of apoptosis, oxidative stress, antioxidant, and steroidogenesis regulation of the bGCs under heat stress

(Additional file 2). Taking all comparisons, it was found that five pathways (Protein processing in the endoplasmic reticulum, FoxO signaling pathway, Apoptosis, p53 signaling pathway, and Pathways in cancer) were shared in all the three comparisons.

\section{Commonly shared genes among all the pathways of the three comparisons}

The total of 142,321 and 294 significantly $(P<0.05)$ DEGs were documented in the three comparisons of Control vs. $39^{\circ} \mathrm{C}$, Control vs. $40^{\circ} \mathrm{C}$, and Control vs. $41{ }^{\circ} \mathrm{C}$, respectively. Out of these DEGs, 55 genes were commonly shared among the three comparisons. Furthermore, 58, 201, and 179 DEGs were found to be unique genes for Control vs. $39^{\circ} \mathrm{C}$, Control vs. $40{ }^{\circ} \mathrm{C}$, and Control vs. $41^{\circ} \mathrm{C}$, respectively (Additional file 3, Fig. 6b).

\section{Regulation of signaling pathways under heat stress affecting bGCs functions}

Heat stress significantly regulated pathways are affecting bGCs physiological attributes i.e. promote the inhibition of cell growth, steroidogenesis, and induction of apoptosis by the accumulation of ROS, etc. These pathways include (MAPK signaling pathway, FoxO signaling pathway, Apoptosis, ovarian steroidogenesis, Protein processing in the endoplasmic reticulum, and Glutathione metabolism. Genes belonging to these canonical pathways were differentially expressed (Fig. 8) in response to HS.

Functional annotation cluster and gene ontology analysis Detailed annotation of molecular gene function, biological process and cellular distribution of differentially expressed genes (DEGs; > = 1.5 fold change) identified by gene ontology (GO) descriptions in response to heat stress in-vitro cultured bGCs was accomplished in order to explore biological significance.

\section{Control vs. $39^{\circ} \mathrm{C}$ comparison}

A total of 58, 24, and 16 biological processes (BP), cellular components (CC) and molecular functions (MF) respectively, were found to be affected by heat stress. 
a

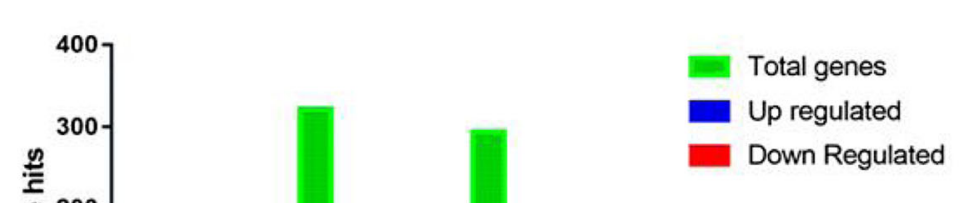

b

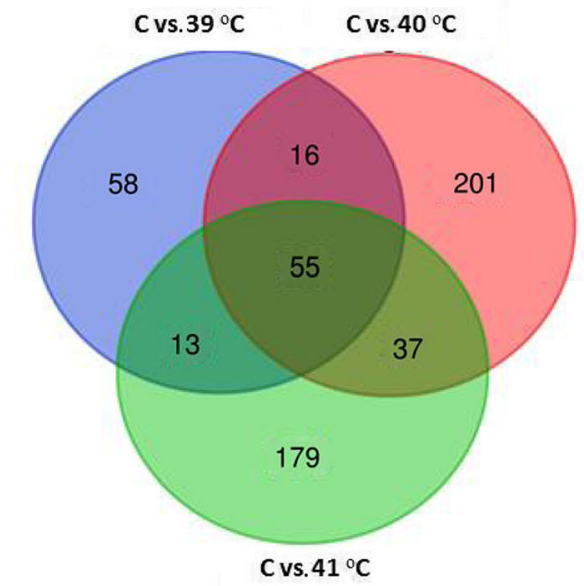

C

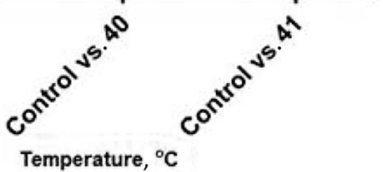

एँ

100
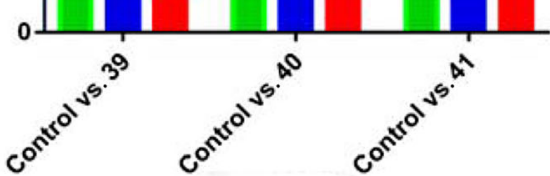

Temperature, ${ }^{\circ} \mathrm{C}$ 38-39-40-41 C Cluster analysis of DEGs

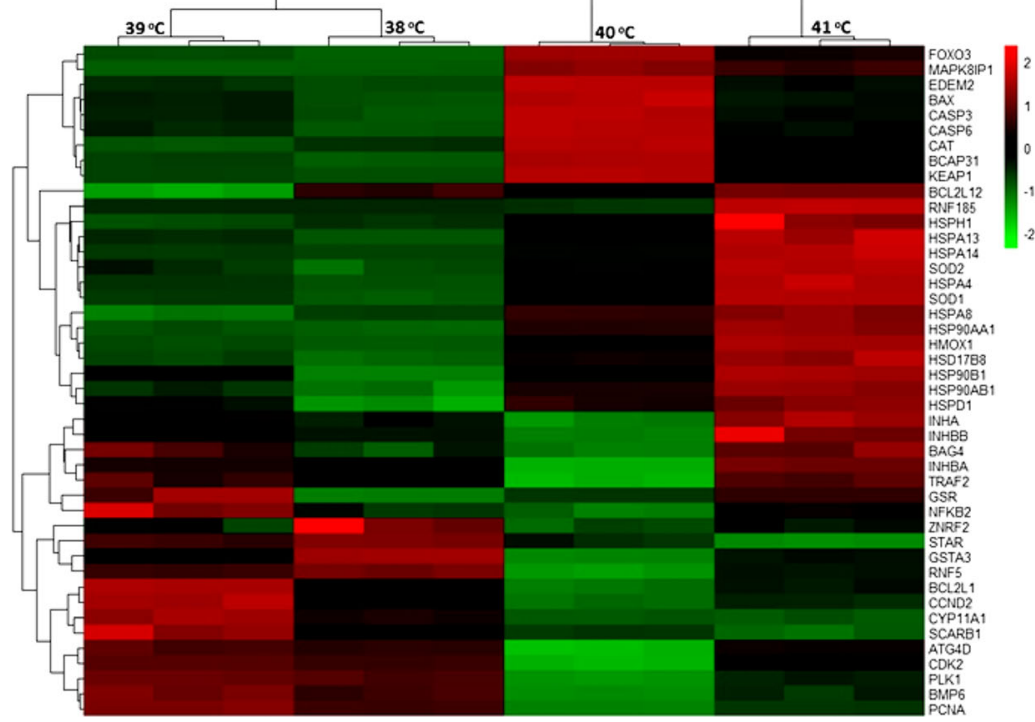

Fig. 6 (See legend on next page.) 
(See figure on previous page.)

Fig. 6 RNA sequencing data Analysis for identifying differentially expressed genes among three groups (Control vs. $39^{\circ} \mathrm{C}$, Control vs. $40^{\circ} \mathrm{C}$ and Control vs. $41{ }^{\circ} \mathrm{C}$ ): DEGs in different comparisons in bGCs. a Graphical representation of significant DEGs disclosed among three comparison groups of bovine granulosa cells cultured under different intensities of heat stress. b Venn diagrams shows overlapping DEGs after heat stress among three comparisons. c. Heatmap of top 45 differentially expressed granulosa cell genes in heat stressed groups with FC $>2, P<0.05$. Red corresponds to up-regulated gene product, and green corresponds to down-regulated gene product. Each differentially expressed gene is represented by a single row, and each heat treatment group is represented by a single column

However, the 35, 14, and 10 were enriched under BP, $\mathrm{CC}$, and MF respectively revealed significant level $(P<$ 0.05). A total of 142 DEGs (54 down-regulated, i.e., CAT, MAPK8IP1, TMCO3 and 88 up-regulated, i.e., $B M P 6, P R D X 6$, and HMOX1) were involved in all GO terms. Among 35 biological processes, major molecular functions, i.e. oxidation-reduction process, regulation of the apoptotic process, cell redox homeostasis, cell development, regulation of MAPK cascade, ovarian follicle development, cholesterol transport, ATP binding, poly(A) RNA binding, and protein homodimerization activity were found to be associated with DEGs. The seven major cellular processes associated with DEGs were the nucleus, cytoplasm, extracellular exosome, cystole, nucleoplasm, and mitochondrion (Additional file 6). A complete list of GO terms and the genes involved in them are given in the (Additional file 4).

\section{Control vs. $40^{\circ} \mathrm{C}$ comparison}

GO analysis was conducted on DEGs ( $\geq 1.5$ fold change) that summarized the major GO terms influenced by heat stress in granulosa cells. DEGs regulated a total of 52 $\mathrm{BP}, 28 \mathrm{CC}$, and $15 \mathrm{MF}$ in Control vs. $40^{\circ} \mathrm{C}$ treated group. Out of them, 40, 21, and 09 showed a significant difference $(P<0.05)$ for $\mathrm{BP}, \mathrm{CC}$, and MF, respectively (Additional file 6). Total of 321 DEGs (169 downregulated, i.e., PCNA, BAG4, BMP6, INHA and 153 upregulated, i.e., $C A S P 3, F O X O 3, K E A P 1)$ were significantly involved in all GO terms. Out of 51 biological function processes, major gene portions were enriched in regulation of the apoptotic process, regulation of cell cycle, protein folding, DNA repair, negative regulation of cholesterol biosynthetic process and superoxide metabolic process (Additional file 6). Similarly, the GO terms for MF included structural constituent of ribosome, protein homodimerization activity, RNA binding, cysteinetype endopeptidase activity, etc. (Additional file 6). Moreover, CC related GO terms were cytoplasm, nucleus, extracellular exosome, mitochondrion, endoplasmic reticulum, etc. (Additional file 6). A complete set of GO terms and the DEGs involved are given in the (Additional file 4).

\section{Control vs. $41^{\circ} \mathrm{C}$ comparison}

A total of 294 DEGs (137 down-regulated, i.e., CYP11A1, STAR, SCARB1and 157 up-regulated, i.e., SOD2,
HSP90AA1, HSPD1) in heat stressed bGCs in the comparison of Control vs. $41^{\circ} \mathrm{C}$ were also assigned with GO terms. A wide range of $\mathrm{GO}$ categories have been identified for the biological process, including cellular response to oxidative stress, negative regulation of the apoptotic process, MAPK cascade regulation, glutathione metabolic process, cellular response to reactive oxygen species, etc.. GO terms for molecular functions were also identified for 294 DEGs that were commonly over expressed at $41^{\circ} \mathrm{C}$. They comprise poly(A) RNA binding, superoxide dismutase activity, protein binding, protein homodimerization activity, etc. (Additional file 6). Similarly, GO terms for cellular components, i.e. cytoplasm, extracellular exosome, Bcl-2 family protein complex, mitochondrion, endoplasmic reticulum, transcription factor complex, etc. were affected (Additional file 6). Data set for all GO terms are shown in the (Additional file 4).

\section{Protein-protein interaction (PPI) networks of DEGs significantly enriched pathways associated with bGCs functions under heat stress}

To get a better insight into the interconnection among DEGs regulated pathways under heat stress, STRING analysis with confidence (0.09) was used to draw an interaction network among the corresponding proteins of the DEGs across all comparisons (Control vs. $39^{\circ} \mathrm{C}$, Control vs. $40^{\circ} \mathrm{C}$ and Control vs. $41{ }^{\circ} \mathrm{C}$ ). The PPI interaction network analysis showed that compared with Control vs. $39^{\circ} \mathrm{C}$ and Control vs. $41^{\circ} \mathrm{C}$, most of the proteins in Control vs. $40^{\circ} \mathrm{C}$ are highly interconnected (Fig. 9a, b, c). Interestingly, the PPI in response to $39^{\circ} \mathrm{C}$ treatment showed that HSP90AA1, BCAR1, PPP5C, CRK, INHA, INHBA, INHBB, DOCK7, and MAPRE1 distributed in the central parts. While in $40^{\circ} \mathrm{C}$ and $41^{\circ} \mathrm{C}$ treated GCs cultured group, PPI network analysis revealed that the HSPs, cochaperones (HSP90AA1, HSP90AB1, HSPA13, HSPA4, HSPA8, HSPA14, HSPD1, HSPH1, BAG4, NUP43, TRAF2, PLK1, etc.) occupied central position and were strongly related and mostly co-expressed.

\section{Validation of RNA-Seq results by RT-qPCR}

To confirm changes in the expression of genes identified in RNA-Seq results, quantitative reverse transcription polymerase chain reaction (RT-qPCR) analyses of 15 
Table 2 List of genes classified in major functional categories during post heat stress (relative to Control) in bGCs

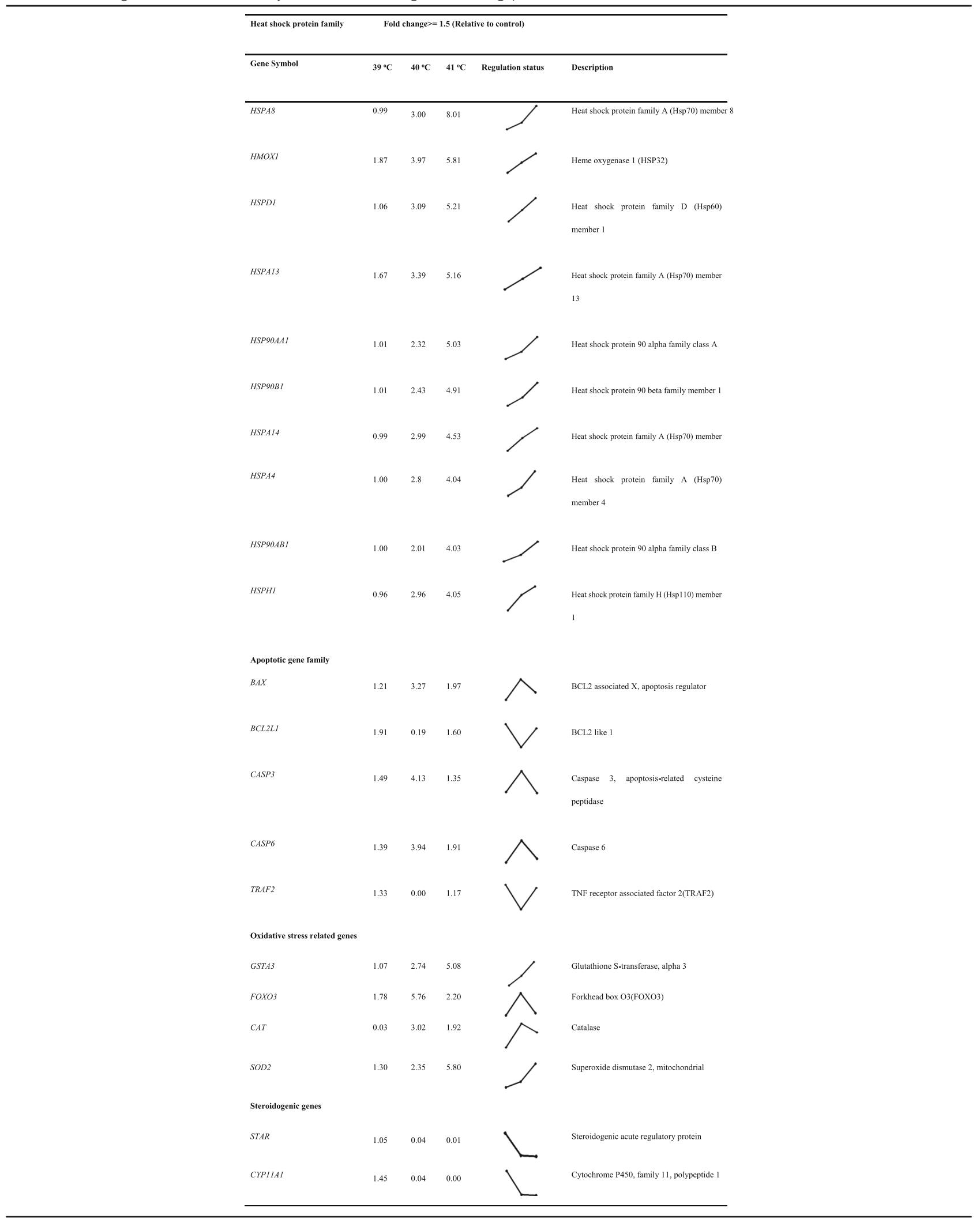


$\mathbf{a}$

Control vs. $39^{\circ} \mathrm{C}$

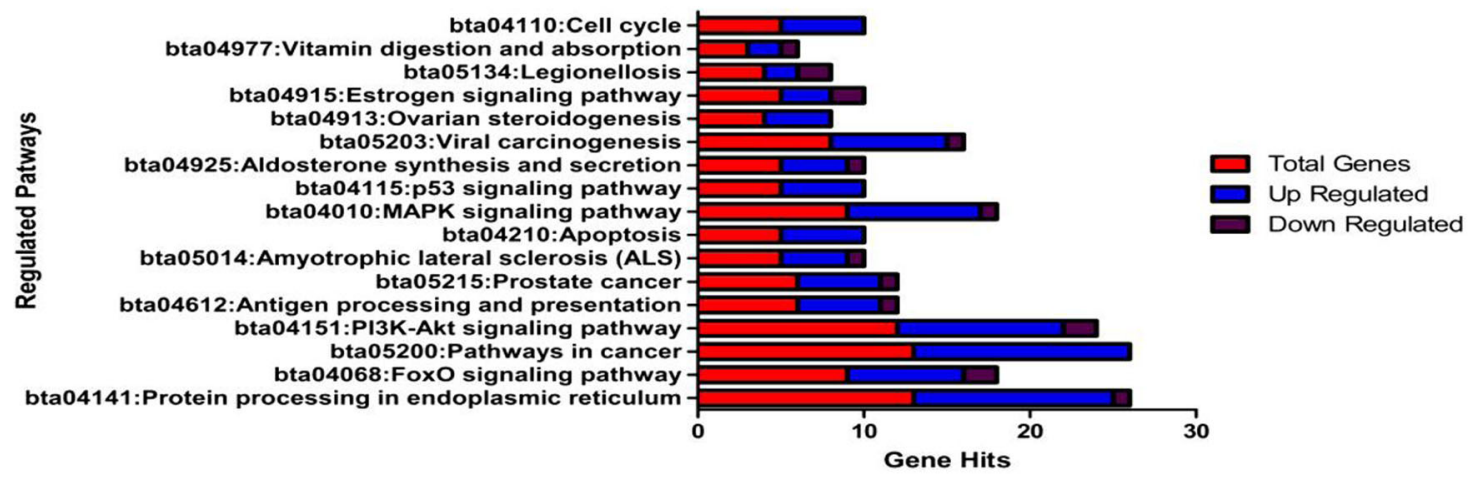

b

\section{Control vs. $40^{\circ} \mathrm{C}$}

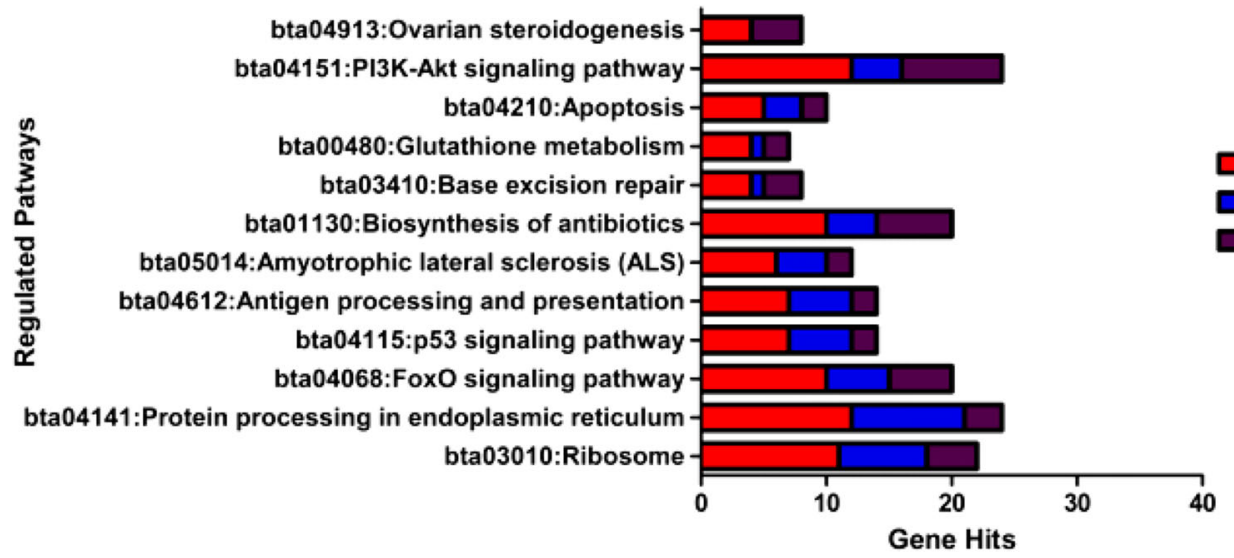

c

\section{Control vs. $41^{\circ} \mathrm{C}$}

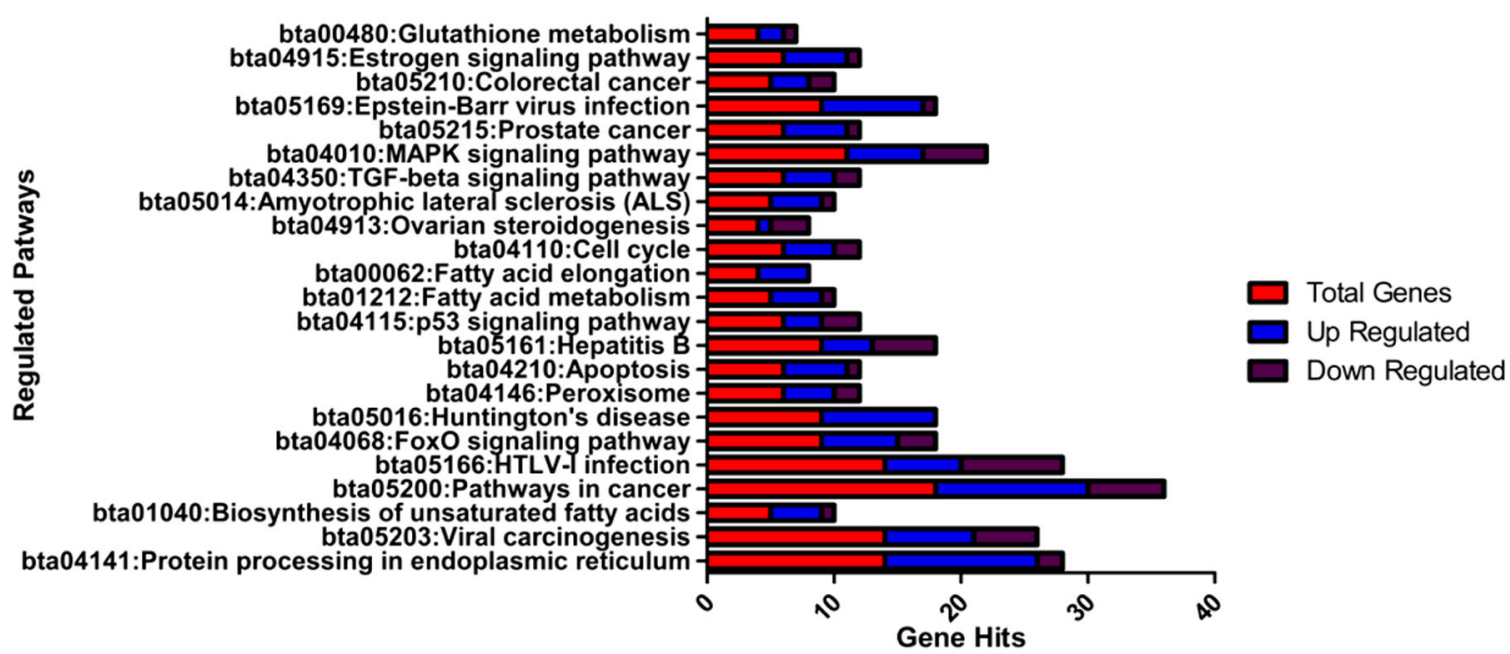

Fig. 7 Pathway analysis of differentially expressed genes among three groups in response to heat stress: Enriched gene pathways in granulosa cells along all comparison of Control vs. 39,40 and $41{ }^{\circ} \mathrm{C}$ cultured groups. Only significantly $(P<0.05)$ regulated pathways with up and down genes were shown $(\mathbf{a}, \mathbf{b}, \mathbf{c})$ 
Table 3 The DEGs and biological pathways regulated in treatment groups (Control vs. $39{ }^{\circ} \mathrm{C}$, Control vs. $40^{\circ} \mathrm{C}$, Control vs. $41^{\circ} \mathrm{C}$ )

\begin{tabular}{|c|c|c|c|}
\hline Pathway name & $\begin{array}{l}\text { Gene } \\
\text { count }\end{array}$ & $\begin{array}{l}P- \\
\text { value }\end{array}$ & Gene name \\
\hline \multicolumn{4}{|l|}{ Control vs. $39^{\circ} \mathrm{C}$} \\
\hline $\begin{array}{l}\text { Protein processing } \\
\text { in endoplasmic } \\
\text { reticulum }\end{array}$ & 13 & $\begin{array}{l}1.23 \mathrm{E}- \\
07\end{array}$ & $\begin{array}{l}\text { HSP9OAB1, TRAF2, HSPH1, ATF4, } \\
\text { HSP9OB1, HSP9OAA1, RNF5, BAX, } \\
\text { RNF185, EDEM2, EIF2AK4, HSPA8, } \\
\text { BCAP31 }\end{array}$ \\
\hline $\begin{array}{l}\text { FoxO signaling } \\
\text { pathway }\end{array}$ & 9 & $\begin{array}{l}5.74 \mathrm{E}- \\
05\end{array}$ & $\begin{array}{l}\text { PLK1, CCND2, MDM2, CAT, } \\
\text { FOXO3, G6PC3, CDK2, SOD2 }\end{array}$ \\
\hline Pathways in cancer & 13 & $\begin{array}{l}7.19 \mathrm{E}- \\
04\end{array}$ & $\begin{array}{l}\text { HSP9OAB1, TRAF2, CASP3, } \\
\text { HSP9OB1, HSP9OAA1, BAX, GNB5, } \\
\text { MDM2, BCL2L1, NFKB2, FGF12, } \\
\text { CRK, CDK2 }\end{array}$ \\
\hline $\begin{array}{l}\text { PI3K-Akt signaling } \\
\text { pathway }\end{array}$ & 12 & $\begin{array}{l}7.77 \mathrm{E}- \\
04\end{array}$ & $\begin{array}{l}\text { HSP9OAB1, ATF4, HSP9OB1, } \\
\text { HSP90AA1, CCND2, GNB5, MDM2, } \\
\text { FOXO3, BCL2L1, FGF12, G6PC3, } \\
\text { CDK2 }\end{array}$ \\
\hline $\begin{array}{l}\text { Antigen } \\
\text { processing and } \\
\text { presentation }\end{array}$ & 6 & $\begin{array}{l}9.96 \mathrm{E}- \\
04\end{array}$ & $\begin{array}{l}\text { HSP90AB1, HSP9OAA1, NFYC, IFI30, } \\
\text { HSPA4, HSPA8 }\end{array}$ \\
\hline $\begin{array}{l}\text { bta05215:Prostate } \\
\text { cancer }\end{array}$ & 6 & $\begin{array}{l}1.80 \mathrm{E}- \\
03\end{array}$ & $\begin{array}{l}\text { HSP9OAB1, ATF4, HSP9OB1, } \\
\text { HSP9OAA1, MDM2, CDK2 }\end{array}$ \\
\hline $\begin{array}{l}\text { Amyotrophic } \\
\text { lateral sclerosis } \\
\text { (ALS) }\end{array}$ & 5 & $\begin{array}{l}2.20 \mathrm{E}- \\
03\end{array}$ & CASP3, BAX, CAT, BCL2L1, SOD1 \\
\hline Apoptosis & 5 & $\begin{array}{l}3.70 \mathrm{E}- \\
03\end{array}$ & CASP6, TRAF2, CASP3, BAX, BCLLL1 \\
\hline $\begin{array}{l}\text { MAPK signaling } \\
\text { pathway }\end{array}$ & 9 & $\begin{array}{l}4.70 \mathrm{E}- \\
03\end{array}$ & $\begin{array}{l}\text { TRAF2, CASP3, ATF4, MAPK8IP1, } \\
\text { NFKB2, FGF12, CRK, HSPA8, PPP5C }\end{array}$ \\
\hline $\begin{array}{l}\text { p53 signaling } \\
\text { pathway }\end{array}$ & 5 & $\begin{array}{l}6.00 \mathrm{E}- \\
03\end{array}$ & CASP3, CCND2, BAX, MDM2, CDK2 \\
\hline $\begin{array}{l}\text { Aldosterone } \\
\text { synthesis and } \\
\text { secretion }\end{array}$ & 5 & $\begin{array}{l}8.70 \mathrm{E}- \\
03\end{array}$ & $\begin{array}{l}\text { ATF4, CYP11A1, STAR, SCARB1, } \\
\text { ATF1 }\end{array}$ \\
\hline $\begin{array}{l}\text { Viral } \\
\text { carcinogenesis }\end{array}$ & 8 & 0.010 & $\begin{array}{l}\text { TRAF2, CASP3, ATF4, CCND2, BAX, } \\
\text { MDM2, NFKB2, CDK2 }\end{array}$ \\
\hline $\begin{array}{l}\text { Ovarian } \\
\text { steroidogenesis }\end{array}$ & 4 & 0.014 & CYP11A1, STAR, SCARB1, BMP6 \\
\hline $\begin{array}{l}\text { Estrogen signaling } \\
\text { pathway }\end{array}$ & 5 & 0.018 & $\begin{array}{l}\text { HSP9OAB1, ATF4, HSP9OB1, } \\
\text { HSP9OAA1, HSPA8 }\end{array}$ \\
\hline Legionellosis & 4 & 0.020 & CASP3, HSPD1, NFKB2, HSPA8 \\
\hline $\begin{array}{l}\text { Vitamin digestion } \\
\text { and absorption }\end{array}$ & 3 & 0.021 & $B T D, A B C C 1, S C A R B 1$ \\
\hline Cell cycle & 5 & 0.039 & PLK1, CCND2, PCNA, MDM2, CDK2 \\
\hline $\begin{array}{l}\text { Epstein-Barr virus } \\
\text { infection }\end{array}$ & 6 & 0.047 & $\begin{array}{l}\text { TRAF2, MDM2, NFKB2, CDK2, } \\
\text { EIF2AK4, HSPA8 }\end{array}$ \\
\hline \multicolumn{4}{|l|}{ Control vs. $40^{\circ} \mathrm{C}$} \\
\hline Ribosome & 11 & $\begin{array}{l}2.18 \mathrm{E}- \\
04\end{array}$ & $\begin{array}{l}\text { RPS26, MRPL23, MRPL21, MRPL15, } \\
\text { RPLPO, RPL15, MRPL36, RPS11, } \\
\text { MRPL33, UBA52, RPS24 }\end{array}$ \\
\hline $\begin{array}{l}\text { Protein processing } \\
\text { in endoplasmic } \\
\text { reticulum }\end{array}$ & 12 & $\begin{array}{l}3.51 \mathrm{E}- \\
04\end{array}$ & $\begin{array}{l}\text { HSP90AB1, TRAF2, HSPH1, } \\
\text { HSP90B1, HSP90AA1, EIF2AK1, } \\
\text { RNF5, BAX, RNF185, EDEM2, } \\
\text { HSPA8, BCAP31 }\end{array}$ \\
\hline FoxO signaling & 10 & 8.75E- & HRAS, PLK1, CCND2, PRKAB1, CAT, \\
\hline
\end{tabular}

Table 3 The DEGs and biological pathways regulated in treatment groups (Control vs. $39^{\circ} \mathrm{C}$, Control vs. $40^{\circ} \mathrm{C}$, Control vs. $41^{\circ} \mathrm{C}$ ) (Continued)

\begin{tabular}{|c|c|c|c|}
\hline Pathway name & $\begin{array}{l}\text { Gene } \\
\text { count }\end{array}$ & $\begin{array}{l}P- \\
\text { value }\end{array}$ & Gene name \\
\hline pathway & & 04 & FOXO3, CCNG2, CDK2, SOD2 \\
\hline $\begin{array}{l}\text { p53 signaling } \\
\text { pathway }\end{array}$ & 7 & 0.002 & $\begin{array}{l}\text { CASP3, CCND2, BAX, TSC2, RPRM, } \\
\text { CCNG2, CDK2 }\end{array}$ \\
\hline $\begin{array}{l}\text { Antigen } \\
\text { processing and } \\
\text { presentation }\end{array}$ & 7 & 0.002 & $\begin{array}{l}\text { HSP9OAB1, CTSL, HSP9OAA1, NFYC, } \\
\text { HSPA4, RFXANK, HSPA8 }\end{array}$ \\
\hline $\begin{array}{l}\text { Amyotrophic } \\
\text { lateral sclerosis } \\
\text { (ALS) }\end{array}$ & 6 & 0.003 & $\begin{array}{l}\text { CASP3, BAX, TOMMAOL, CAT, } \\
\text { BCL2L1, SOD1 }\end{array}$ \\
\hline $\begin{array}{l}\text { Biosynthesis of } \\
\text { antibiotics }\end{array}$ & 10 & 0.016 & $\begin{array}{l}\text { SC5D, UAP1, IDH3G, PAFAH2, } \\
\text { PGM1, RCE1, CAT, UAP1L1, PAICS, } \\
\text { OAT }\end{array}$ \\
\hline $\begin{array}{l}\text { Base excision } \\
\text { repair }\end{array}$ & 4 & 0.024 & LIG3, PCNA, OGG1, APEX1 \\
\hline $\begin{array}{l}\text { Glutathione } \\
\text { metabolism }\end{array}$ & 3 & 0.026 & GSS, GSR, GSTA3 \\
\hline Apoptosis & 5 & 0.029 & CASPG, TRAF2, CASP3, BAX, BCL2L1 \\
\hline $\begin{array}{l}\text { PI3K-Akt signaling } \\
\text { pathway }\end{array}$ & 12 & 0.035 & $\begin{array}{l}\text { HSP9OAB1, HRAS, HSP9OB1, } \\
\text { HSP9OAA1, CCND2, TSC2, GNG2, } \\
\text { FOXO3, BCL2L1, FGF12, CDK2, } \\
\text { GHR }\end{array}$ \\
\hline $\begin{array}{l}\text { Ovarian } \\
\text { steroidogenesis }\end{array}$ & 4 & 0.038 & CYP11A1, STAR, SCARB1, BMP6 \\
\hline \multicolumn{4}{|l|}{ Control vs $41^{\circ} \mathrm{C}$} \\
\hline $\begin{array}{l}\text { Protein processing } \\
\text { in endoplasmic } \\
\text { reticulum }\end{array}$ & 14 & $\begin{array}{l}1.40 \mathrm{E}- \\
05\end{array}$ & $\begin{array}{l}\text { HSP9OAB1, TRAF2, HSP9OAA1, } \\
\text { RNF185, EDEM2, BCAP31, HSPH1, } \\
\text { HSP9OB1, EIF2AK1, DNAJB11, } \\
\text { RNF5, BAX, EIF2AK2, HSPA8 }\end{array}$ \\
\hline $\begin{array}{l}\text { Viral } \\
\text { carcinogenesis }\end{array}$ & 14 & $\begin{array}{l}3.92 \mathrm{E}- \\
04\end{array}$ & $\begin{array}{l}\text { TRAF2, CASP3, HDAC1, CCND2, } \\
\text { DDB1, BAX, CREBBP, RHOA, } \\
\text { PIK3CA, NFKB2, EIF2AK2, SRF, } \\
\text { CDK2, SCRIB }\end{array}$ \\
\hline $\begin{array}{l}\text { Biosynthesis of } \\
\text { unsaturated fatty } \\
\text { acids }\end{array}$ & 5 & $\begin{array}{l}9.11 \mathrm{E}- \\
04\end{array}$ & $\begin{array}{l}\text { PECR, ACOT7, ELOVL5, HACD2, } \\
\text { FADS2 }\end{array}$ \\
\hline Pathways in cancer & 18 & 0.001 & $\begin{array}{l}\text { HSP9OAB1, DVL2, TRAF2, } \\
\text { HSP9OAA1, EPAS1, CREBBP, } \\
\text { BCL2L1, KIT, NFKB2, CDK2, VEGFC, } \\
\text { FOS, CASP3, HSP9OB1, HDAC1, } \\
\text { BAX, RHOA, PIK3CA }\end{array}$ \\
\hline HTLV-I infection & 14 & 0.001 & $\begin{array}{l}\text { DVL2, TSPO, MRAS, CREBBP, } \\
\text { NFKB2, BCLLL1, SRF, FOS, CCND2, } \\
\text { BAX, PCNA, RRAS, PIK3CA, NFATC3 }\end{array}$ \\
\hline $\begin{array}{l}\text { FoxO signaling } \\
\text { pathway }\end{array}$ & 9 & 0.003 & $\begin{array}{l}\text { PLK1, CCND2, CREBBP, PIK3CA, } \\
\text { CAT, FOXO3, CDK2, SOD2 }\end{array}$ \\
\hline $\begin{array}{l}\text { Huntington's } \\
\text { disease }\end{array}$ & 9 & 0.003 & $\begin{array}{l}\text { CASP3, HDAC1, BAX, CREBBP, } \\
\text { NDUFV2, NDUFS3, SOD1, SOD2 }\end{array}$ \\
\hline Peroxisome & 6 & 0.004 & $\begin{array}{l}\text { PECR, PEX2, MPV17, CAT, SOD1, } \\
\text { SOD2 }\end{array}$ \\
\hline Apoptosis & 6 & 0.005 & $\begin{array}{l}\text { CASP6, TRAF2, CASP3, BAX, } \\
\text { PIK3CA, BCLLL1 }\end{array}$ \\
\hline Hepatitis B & 9 & 0.006 & $\begin{array}{l}\text { FOS, CASP3, DDB1, BAX, CREBBP, } \\
\text { PCNA, PIK3CA, NFATC3, CDK2 }\end{array}$ \\
\hline
\end{tabular}


Table 3 The DEGs and biological pathways regulated in treatment groups (Control vs. $39^{\circ} \mathrm{C}$, Control vs. $40{ }^{\circ} \mathrm{C}$, Control vs. $\left.41^{\circ} \mathrm{C}\right)$ (Continued)

\begin{tabular}{|c|c|c|c|}
\hline Pathway name & $\begin{array}{l}\text { Gene } \\
\text { count }\end{array}$ & $\begin{array}{l}P \text { - } \\
\text { value }\end{array}$ & Gene name \\
\hline $\begin{array}{l}\text { p53 signaling } \\
\text { pathway }\end{array}$ & 6 & 0.010 & CASP3, CCND2, CD82, BAX, CDK2 \\
\hline $\begin{array}{l}\text { Fatty acid } \\
\text { metabolism }\end{array}$ & 5 & 0.011 & $\begin{array}{l}\text { PECR, ELOVL5, HACD2, FADS2, } \\
\text { HADH }\end{array}$ \\
\hline $\begin{array}{l}\text { Fatty acid } \\
\text { elongation }\end{array}$ & 4 & 0.011 & ACOT7, ELOVL5, HACD2, HADH \\
\hline Cell cycle & 6 & 0.013 & $\begin{array}{l}\text { HDAC1, PLK1, CCND2, CREBBP, } \\
\text { PCNA, CDK2 }\end{array}$ \\
\hline $\begin{array}{l}\text { Ovarian } \\
\text { steroidogenesis }\end{array}$ & 4 & 0.015 & CYP11A1, STAR, SCARB1, BMP6 \\
\hline $\begin{array}{l}\text { Amyotrophic } \\
\text { lateral sclerosis } \\
\text { (ALS) }\end{array}$ & 5 & 0.017 & CASP3, BAX, CAT, BCL2L1, SOD1 \\
\hline $\begin{array}{l}\text { TGF-beta signaling } \\
\text { pathway }\end{array}$ & 6 & 0.018 & $\begin{array}{l}\text { INHBB, INHBA, CREBBP, RHOA, } \\
\text { TGIF2, BMP6 }\end{array}$ \\
\hline $\begin{array}{l}\text { MAPK signaling } \\
\text { pathway }\end{array}$ & 11 & 0.021 & $\begin{array}{l}\text { TRAF2, FOS, CASP3, MRAS, PTPRR, } \\
\text { RRAS, MAPKBIP1, NFKB2, NFATC3, } \\
\text { SRF, HSPA8 }\end{array}$ \\
\hline Prostate cancer & 6 & 0.021 & $\begin{array}{l}\text { HSP9OAB1, HSP9OB1, HSP9OAA1, } \\
\text { CREBBP, PIK3CA, CDK2 }\end{array}$ \\
\hline $\begin{array}{l}\text { Epstein-Barr virus } \\
\text { infection }\end{array}$ & 9 & 0.026 & $\begin{array}{l}\text { TRAF2, EIF2AK1, HDAC1, CREBBP, } \\
\text { PIK3CA, NFKB2, EIF2AK2, CDK2, } \\
\text { HSPA8 }\end{array}$ \\
\hline Colorectal cancer & 5 & 0.0339 & FOS, CASP3, BAX, RHOA, PIK3CA \\
\hline $\begin{array}{l}\text { Estrogen signaling } \\
\text { pathway }\end{array}$ & 6 & 0.0354 & $\begin{array}{l}\text { HSP9OAB1, FOS, HSP9OB1, } \\
\text { HSP9OAA1, PIK3CA, HSPAB }\end{array}$ \\
\hline $\begin{array}{l}\text { Glutathione } \\
\text { metabolism }\end{array}$ & 3 & 0.0386 & GSR, GSTA3, G6PD \\
\hline
\end{tabular}

representative genes were performed on the same samples (Additional file 5). Gene expression profiling of granulosa cells showed that some HSP family-related genes were active during cellular heat response (Table 2). The expressions of HSP family genes such as HSPA13, HMOX1, apoptotic-related genes (CASP3, BAX and BCL2L1), steroidogenic genes (CYP11A1, STAR) antioxidant activity-related genes (SOD2, CAT, GSTA3) and genes related to oxidative stress (FOXO3 and MAPK8IP1) were significantly $(P<0.05)$ regulated across all heat-treated granulosa cells compared to the control group. The results showed that all the genes had similar expression trends as detected in the RNA-Seq. This consistency between RT-qPCR and RNA-Seq revealed the reliability of our RNA-Seq data (Additional file 6).

\section{Discussion}

Environmental factors, particularly temperature, have a significant impact on animal breeding and reproduction [22]. Heat stress can be defined as a condition that occurs when an animal can not dissipate body heat adequately to maintain thermal equilibrium [23, 24]. Heat is proteotoxic stress and causes denatured proteins that, by forming aggregates, can become cytotoxic [25]. The ovarian follicle's granulosa cells play a crucial role in oocyte nourishing, secreting hormones that create functional bidirectional crosstalk with the oocyte [26]. A brief overview of the current study and mechanisms of regulating heat stress response related to follicular function within the bovine ovary is shown in Fig. 10.

In the present study, bGCs were exposed to different levels of in-vitro heat stress and found that heat stress involves compromising the physiological functions of bGCs by increasing intracellular accumulation of ROS, inducing apoptosis and reducing the synthesis of E2 and $\mathrm{P} 4[7,9,15]$. For more understanding, we conducted the transcriptomic study of in-vitro cultured bGCs exposed to heat stress at 39,40 , and $41^{\circ} \mathrm{C}$. Amongst the several hundred genes induced or repressed due to heat stress in-vitro, an attempt was taken to screen out genes associated with, heat shock protein family, apoptosis, steroidogenesis and oxidative stress (Table 2). As expected, the whole set of genes of heat shock family viz., HSPA8, HSPA14, HSP90AA1, HMOX 1, etc. were up-regulated in bGCs at most of the heat stress points. The expression of these genes was more at $41^{\circ} \mathrm{C}$ of heat stress as compared to other treated groups $\left(39,40^{\circ} \mathrm{C}\right)$. Our findings are supported by previous studies that led to the induction of HSP genes by heat stress [27, 28]. Similar to our study, HSPs induction was reported in various cell/ tissue types such as leukocytes/lymphocytes [29-31], bovine endometrial tissue, bovine conceptuses [32, 33], bovine granulosa cells [34] bovine MECs [22], buffalo lymphocytes [35] due to heat stress. It has been reported that heat stress causes an increase in HSPs in virtually all the vertebrates, including mice [36, 37] domestic goats [38], humans [39, 40], juvenile Hamadryads baboons [41], common carp [42], domestic chickens [4346] and domestic turkey [47]. Our results showed an increased accumulation of inducible HSP70 in heat stressed groups at both the protein and mRNA levels, thus supporting the idea that HSP70 can act as a reliable thermal stress biomarker [42, 48]. Likewise, several apoptosis-related genes like $B C L 2$ associated X, apoptosis regulator $(B A X)$, caspase 3 , apoptosis-related cysteine peptidase $(C A S P 3)$ and $(C A S P 6)$, etc. were also found to be significantly $(P<0.05)$ up-regulated under heat stress that signal through the apoptosis signaling pathway. Up-regulation of apoptotic genes could lead to disruption of the potential of mitochondrion transmembrane, resulting in the release of cytochrome $\mathrm{c}$ leading to apoptosis induction [49]. Data on the induced expression of apoptotic genes at $40{ }^{\circ} \mathrm{C}$ suggest that the cellular mechanism may not provide protection for bGCs against 


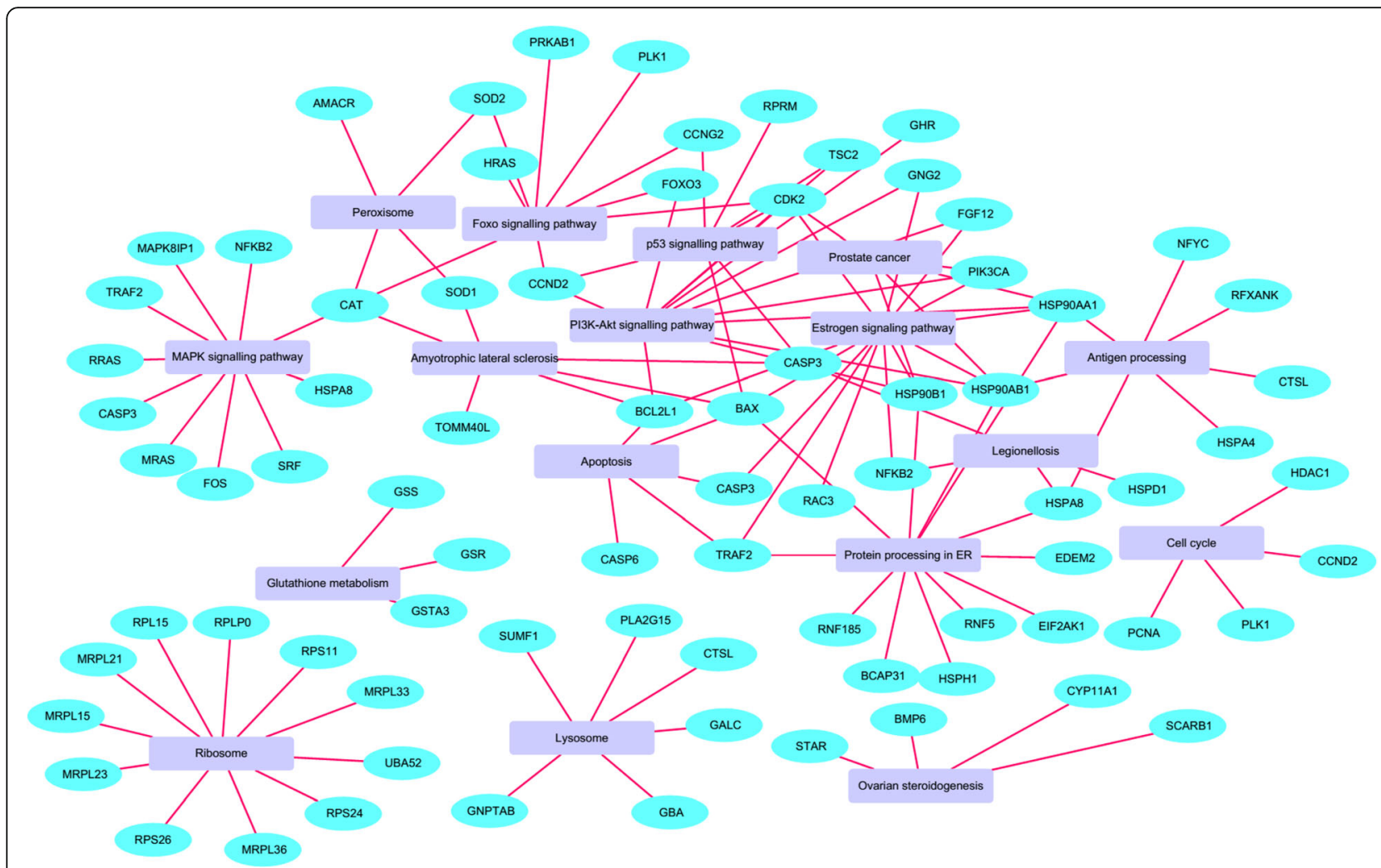

Fig. 8 Regulation of signaling pathways under heat stress affecting bGCs functions: A network map of pathways significantly $(P<0.05)$ enriched after heat stress. The nodes are the pathways, and edges connect the genes involved in the pathway

heat-induced apoptosis while the rate of apoptosis decreased at $41{ }^{\circ} \mathrm{C}$ of heat stress due to over-expression of HSP70, HSP9O and HSP60 protein levels likely helped bGCs activate self-protection mechanisms and cope with hyperthermia through clearance of damaged proteins. Our results are in line with some previous reports where the MAPK mediated induction of HSP70 at high temperature could play a crucial role in inhibiting caspase- 3 and $B A X$ activation [50, 51]. Therefore, we suggest that the induction of $H S P 70$ occurs to reduce apoptosis of granulosa cells induced by heat stress. This is a first study that unveiled the effect of heat stress with different intensities on apoptosis-related gene expression and on the cellular defensive mechanism in bGCs.

Heat stress results in intracellular ROS accumulation, causing oxidative stress [52] and apoptosis [53], which subsequently lead to a decline in fertility $[54,55]$. Moreover, the current study also shows for the first time induction of ROS at different intensities of heat stress in bGCs. Compared to the control, significant $(P<0.05)$ ROS accumulation was evident at $40{ }^{\circ} \mathrm{C}$ and $41{ }^{\circ} \mathrm{C}$ of heat stress, but at $39^{\circ} \mathrm{C}$ the ROS induction was not significant. We found a decline in ROS levels in bGCs by increasing treatment temperature from $40{ }^{\circ} \mathrm{C}$ to $41^{\circ} \mathrm{C}$.
This may be due to the cells being able to activate their antioxidant systems at a higher temperature of $41^{\circ} \mathrm{C}$, by regulating genes, i.e. superoxide dismutase 1, 2 (SOD1, SOD2,), glutathione-disulfide reductase (GSR) and glutathione S-transferase, alpha 3 (GSTA3) to protect cells against oxidative stress. In addition, the high expression of HMOX1 gene was observed in the culture of human melanoma cells, confirming the induction of cellular oxidative stress during harmful insults [56]. Similar to our results, the activation of forkhead box $\mathrm{O} 3$ (FoxO3) and kelch-like ECH associated protein 1 (KEAP1) under heat stress protects cells from oxidative stress by upregulating antioxidant enzymes superoxide dismutase 2 (SOD2) and catalase (CAT) [57-59]. In Saccharomyces cerevisiae and quail, genes from the glutathione peroxidase family were also shown to be induced under heat stress $[60,61]$. Based on these facts, it is reasonable to suggest that the up-regulation expression of SOD2 and $C A T$ may inhibit ROS biosynthesis through the regulation of KEAP1and FOXO3 in ovarian granulosa cells.

Moreover, the regulation of genes related to steroidogenesis, i.e. steroidogenic acute regulatory protein (STAR) and Cytochrome P450, family 11, subfamily A, polypeptide 1 (CYP11A1) was also affected by heat 

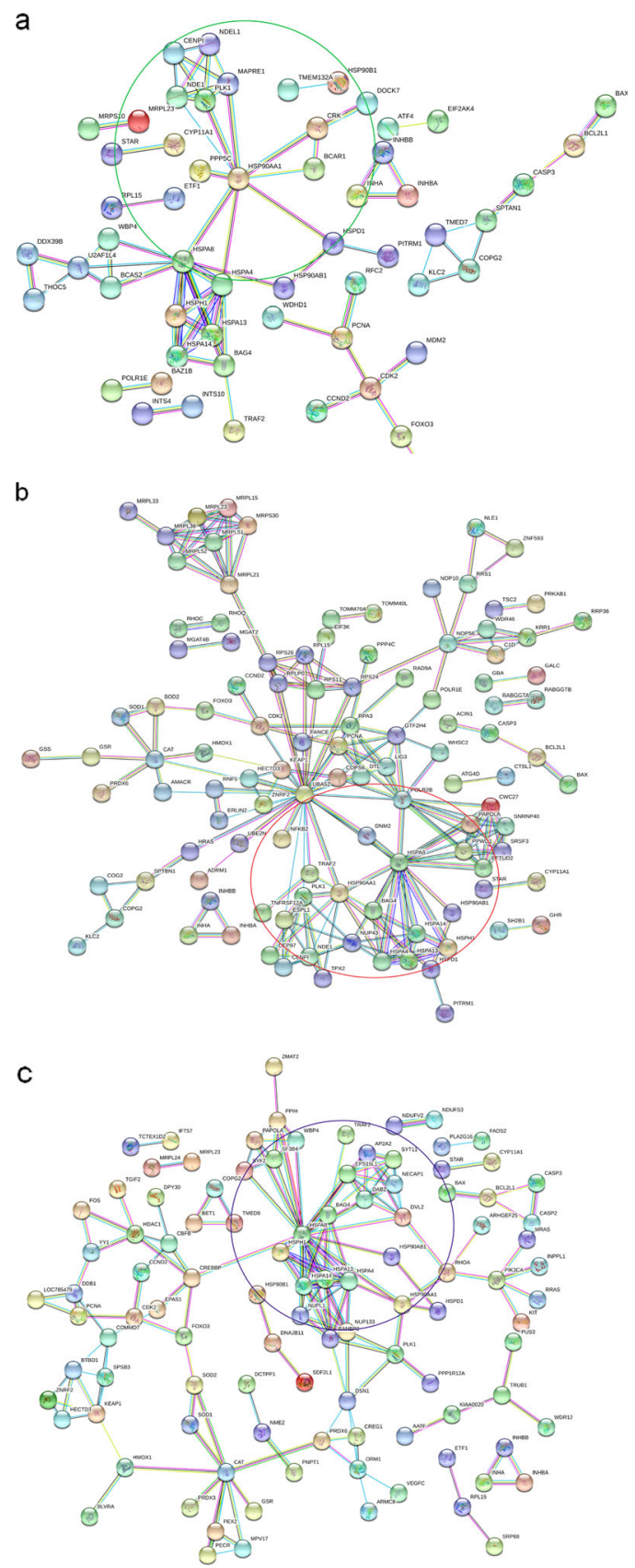

Fig. 9 Protein-protein interaction (PPI) networks of DEGs significantly enriched pathways associated with bGCs functions under heat stress: Protein-protein interaction (PPI) networks in the comparison of Control vs. $39^{\circ} \mathrm{C}$ (a) Control vs. $40^{\circ} \mathrm{C}$ (b) and Control vs. $41^{\circ} \mathrm{C}$ (c). Various color lines represent seven types of evidence used in predicting associations. Red line: fusion evidence; blue line: co-occurrence evidence; yellow line: text mining evidence; green line: neighborhood evidence; purple line: experimental evidence; light blue line: database evidence; and the black line: co-expression evidence

shock. Previously it was reported that heat stress could inhibit estradiol biosynthesis in bGCs and impair hormone balance [62]. Positive regulation of $\mathrm{P} 450$ aromatase family genes (CYP11A1) in the ovarian follicle promotes estrogen biosynthesis [63]. In our study, the mRNA expression of CYP11A1 decreased in GCs by down-regulation of ovarian steroidogenesis signaling pathway after heat treatment that resulted in a decreased level of $E_{2}$ in the culture medium. Based on this confirmation, we can postulate that the down-regulation of CYP11A1 may inhibit estrogen biosynthesis in ovarian granulosa cells. In addition, progesterone is also one of 


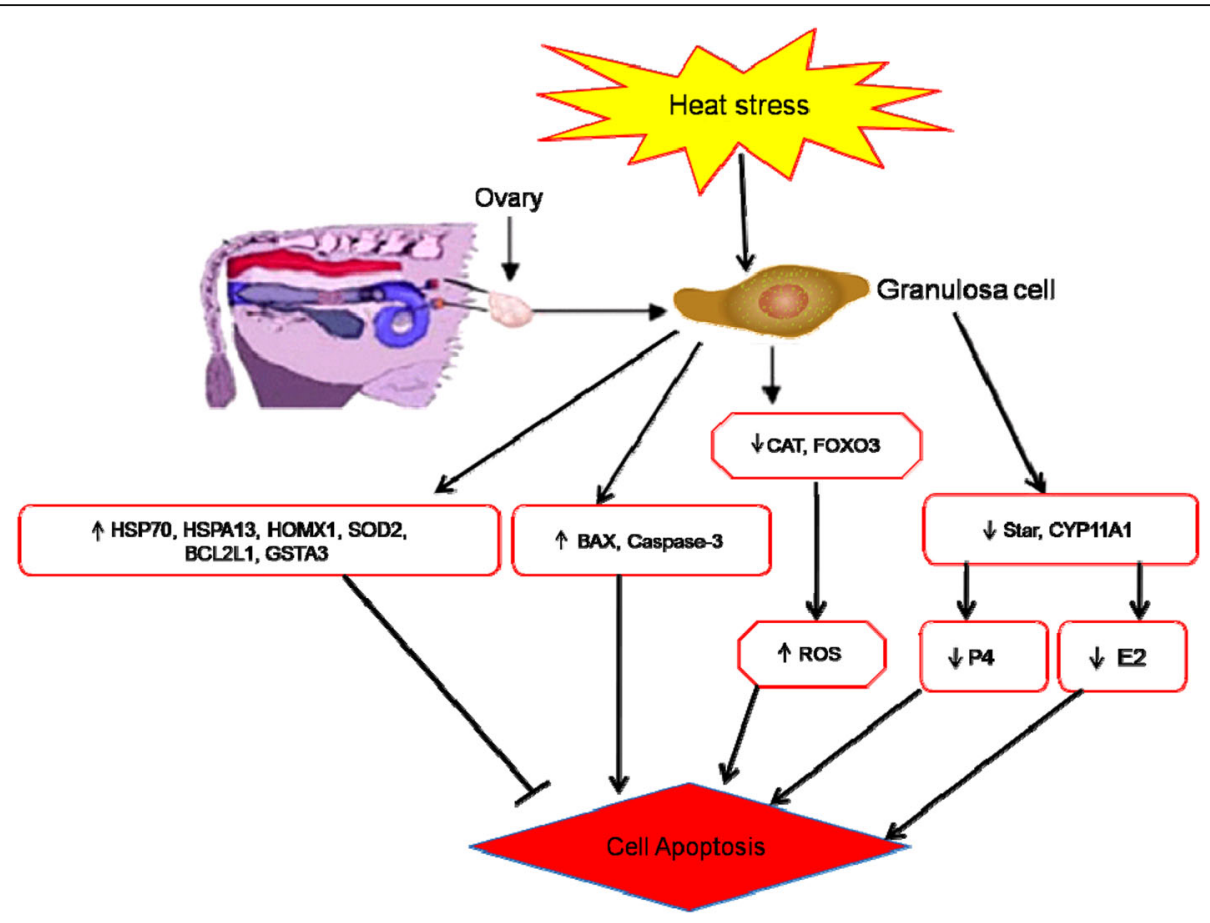

Fig. 10 Research review: Mechanisms of regulating heat stress response related to follicular function within bovine ovary. Upregulated genes caspase-3, SOD, BCL-2, BAX, and HSPs (HSP70, HSPA13, HMOX1) were involved in the regulating mechanism of bGCs via induced or inhibited cell apoptosis. Under heat stress, Down-regulated genes CAT, FOXO3 were involved in production of reactive oxygen species (ROS). Likewise, downregulation of STAR, and CYP11A1 were involved in the secretion of $E_{2}$ and $P_{4}$. Moreover, the decline of $E_{2}$, and enhancing of ROS in turn, might enhance the possibility of GC apoptosis and follicle function

the fundamental steroid hormones for bovine estrous cycle regulation, and its biosynthesis is attributed to the increased expression of STAR and CYP11A1 [64-66]. Previously it was reported that under heat stress, the mRNA expression of CYP11A1 and STAR decreased, but the $\mathrm{P} 4$ level has no significant $(P<0.05)$ difference between the control and heat treatment group [9]. An over-secretion of ovarian hormones in porcine ovarian granulosa cells were reported under high temperature [67]. Our findings are in line with the previous studies where heat stress attenuates estrogenic activity in rat granulosa cells by diminishing the expression of gonadotropin receptor [68]. We also found a lower mRNA expression of the genes CYP11A1 and STAR in heattreated groups. This is the first study to establish the impact of different intensities of thermal stress on the synthesis of steroid hormones and gene expression profile in bGCs. These findings have provided evidence to suggest the varied expression profile in bGCs during heat stress of apoptotic, steroidogenesis and oxidative stress-related genes. In the current study, the RT-qPCR analysis thus validated the transcriptional expression profile of HSPs, apoptotic genes, steroidogenesis, and oxidative stress-related genes as observed by RNA-Seq analysis. Our research can further be extended to understand bovine oocyte modulation and embryo development in response to the environmental heat load.

\section{Conclusion}

In the present study, we demonstrated for the first time a worthy strategy to characterize the cellular and transcriptomic adaptation of bovine granulosa cells to different heat stress intensities $\left(39^{\circ} \mathrm{C}, 40^{\circ} \mathrm{C}\right.$ and $41{ }^{\circ} \mathrm{C}$ ) in-vitro. Furthermore, our data suggested that $40{ }^{\circ} \mathrm{C}$ heat treatment is comparatively detrimental for bovine granulosa cell functions. The study identified several heat-responsive genes from different functional classes and their associated pathways related to heat stress chaperons, cell death, and apoptosis, hormonal synthesis, oxidative stress, etc. known to be affected by heat stress. The results infer that these genes and pathways reported in the present study could be useful candidates/indicators for heat stress research in dairy cattle. Moreover, the established model of bGCs to heat stress in the current study provides an appropriate platform to understand the mechanism of how heat-stressed bGCs can affect the quality of oocytes and developing embryo. 


\section{Supplementary information}

Supplementary information accompanies this paper at https://doi.org/10. 1186/s40104-019-0408-8.

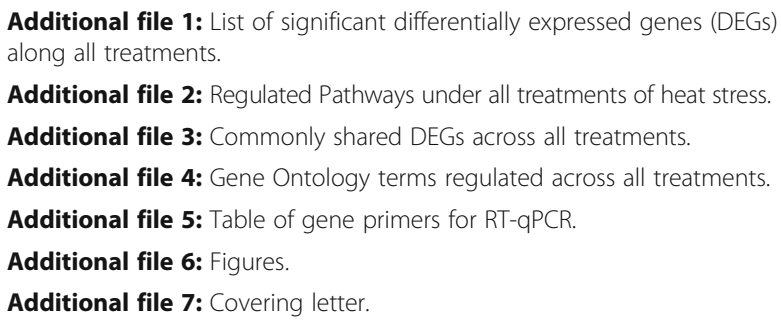

Additional file 1: List of significant differentially expressed genes (DEGs) along all treatments.

Additional file 2: Regulated Pathways under all treatments of heat stress.

Additional file 3: Commonly shared DEGs across all treatments.

Additional file 4: Gene Ontology terms regulated across all treatments.

Additional file 5: Table of gene primers for RT-qPCR.

Additional file 6: Figures.

Additional file 7: Covering letter.

\section{Abbreviations}

bGC: Bovine Granulosa cell; BP: Biological Process; CC: Cellular Components; COC: Cumulus Oocyte Complex; DEGs: Differentially Expressed Genes; DPBS: Dulbecco's Phosphate-Buffered Saline; E2: Estradiol; GO: Gene Ontology; HS: Heat Stress; HSPs: Heat Shock Proteins; KEGG: Kyoto Encyclopedia of Genes and Genomes; MF: Molecular Functions; $\mathrm{P}_{4}$ : Progesterone; PPI: Protein-Protein Interaction; RNA-Seq: RNA sequencing ROS: Reactive Oxygen Species; RT-qPCR: Quantitative Reverse Transcription Polymerase Chain Reaction; THI: Temperature Humidity Index

\section{Acknowledgements}

We acknowledge financial support by Modern Agro-industry Technology Research System (CARS-36); the Program for Changjiang Scholar and Innovation Research Team in University (IRT 15R62).

\section{Conflict of interest}

The authors have no conflict of interest that could be perceived as prejudicing the impartiality of the research reported.

\section{Authors' contributions}

AK performed experiments and wrote the manuscript with figures. XJ helped in experiments. DJ helped in analyzing RNA-Seq data and statistical analysis. HPL helped in collecting farm data. MZK contributed to the proof reading. WY, $\mathrm{HZ}$ and TU designed the project and revised the manuscript. All authors read and approved the final manuscript.

\section{Funding}

The research was funded by Modern Agro-industry Technology Research System (CARS-36); the Program for Changjiang Scholar and Innovation Research Team in University (IRT_15R62). The funders had no role in study design, data collection, analysis, decision to publish, and preparation of the manuscript.

\section{Availability of data and materials}

All data generated or analyzed during this study available from the corresponding authors on reasonable request.

\section{Ethics approval}

This study protocols for the collection of bovine ovaries from experimental animals were reviewed and approved by the institutional animal care and use committee of China Agricultural University Beijing, China (permit number: DK996).

\section{Competing interests}

The authors declare that they have no competing interests.

\section{Author details}

'Key Laboratory of Animal Genetics, Breeding, and Reproduction, MARA; National Engineering Laboratory for Animal Breeding, College of Animal Science and Technology, China Agricultural University, Beijing 100193, People's Republic of China. ${ }^{2}$ Embryo Biotechnology and Reproduction Laboratory, Institute of Animal Sciences, Chinese Academy of Agricultural Sciences, Beijing, China. ${ }^{3}$ College of Veterinary Sciences and Animal Husbandry, Abdul Wali Khan University, Mardan 23200, Pakistan.
Received: 8 July 2019 Accepted: 26 November 2019

Published online: 18 February 2020

\section{References}

1. Su YQ, Wu X, O'Brien MJ, Pendola FL, Denegre JN, Matzuk MM. Synergistic roles of BMP15 and GDF9 in the development and function of the oocytecumulus cell complex in mice: genetic evidence for an oocyte-granulosa cell regulatory loop. Dev Biol. 2004;276(1):64-73.

2. Petro EM, Leroy JL, Van Cruchten SJ, Covaci A, Jorssen EP, Bols PE. Endocrine disruptors and female fertility: focus on (bovine) ovarian follicular physiology. Theriogenology. 2012;78:1887-900.

3. Eppig JJ. Oocyte control of ovarian follicular development and function in mammals. Reproduction. 2001;122(6):829 38 .

4. Bettaieb A, Averill-Bates DA. Thermotolerance induced at a fever temperature of 40 degrees $C$ protects cells against hyperthermia-induced apoptosis mediated by death receptor signalling. Biochem Cell Biol. 2008;86:521-38

5. Wegner K, Lambertz C, Das G, Reiner G, Gauly M. Effects of temperature and temperature-humidity index on the reproductive performance of sows during summer months under a temperate climate. Anim Sci J. 2016;87(11):1334-9.

6. Hansen PJ, Arechiga CF. Strategies for managing reproduction in the heatstressed dairy cow. J Anim Sci. 1999;77(Suppl 2):36-50.

7. Roth Z, Arav A, Bor A, Zeron Y, Braw-Tal R, Wolfenson D. Improvement of quality of oocytes collected in the autumn by enhanced removal of impaired follicles from previously heat-stressed cows. Reprod. 2001:122(5):737-44.

8. Sirotkin AV. Effect of two types of stress (heat shock/high temperature and malnutrition/serum deprivation) on porcine ovarian cell functions and their response to hormones. J Exp Biol. 2010;213(12):2125-30.

9. Li J, Gao H, Tian Z, Wu Y, Wang Y, Fang Y. Effects of chronic heat stress on granulosa cell apoptosis and follicular atresia in mouse ovary. J Anim Sci Biotechnol. 2016;7:57.

10. Calderwood SK, Stevenson MA, Murshid A. Heat shock proteins, autoimmunity, and cancer treatment. J Rheumatol Autoimmune Dis. 2012; 2012:486069.

11. Hou CH, Lin FL, Hou SM, Liu JF. Hyperthermia induces apoptosis through endoplasmic reticulum and reactive oxygen species in human osteosarcoma cells. Int J Mol Sci. 2014;15(10):17380-95.

12. Samoylenko A, Hossain JA, Mennerich D, Kellokumpu S, Hiltunen JK, Kietzmann T. Nutritional countermeasures targeting reactive oxygen species in cancer: from mechanisms to biomarkers and clinical evidence. Antioxid Redox Signal. 2013;19(17):2157-96.

13. Stetler RA, Gan Y, Zhang W, Liou AK, Gao Y, Cao G. Heat shock proteins: cellular and molecular mechanisms in the central nervous system. Prog Neurobiol. 2010;92(2):184-211.

14. Paul C, Teng S, Saunders PT. A single, mild, transient scrotal heat stress causes hypoxia and oxidative stress in mouse testes, which induces germ cell death. Biol Reprod. 2009:80(5):913-9.

15. Liu ZQ, Shen M, Wu WJ, Li BJ, Weng QN, Li M. Expression of PUMA in Follicular Granulosa Cells Regulated by FoxO1 Activation During Oxidative Stress. Reprod Sci. 2015;22(6):696-705

16. Blondin P, Coenen $\mathrm{K}$, Sirard MA. The impact of reactive oxygen species on bovine sperm fertilizing ability and oocyte maturation. J Androl. 1997:18(4):454-60

17. Marshall A, Lukk M, Kutter C, Davies S, Alexander G, Odom DT. Global gene expression profiling reveals SPINK1 as a potential hepatocellular carcinoma marker. PLoS One. 2013;8:e59459.

18. Costa V, Aprile M, Esposito R, Ciccodicola A. RNA-Seq and human complex diseases: recent accomplishments and future perspectives. Eur J Hum Genet. 2013;21:134-42.

19. Pertea M, Daehwan K, Geo MP, Jeffrey TL, Steven LS. Transcript-level expression analysis of RNA-seq experiments with HISAT, StringTie and Ballgown. Nat Protoc. 2016;11(9):1650-67.

20. Karla JH, David FA. An oocentric view of folliculogenesis and embryogenesis. Reprod BioMed. 2007;14(6):758-64.

21. Huang DW, Sherman BT, Lempicki RA. Systematic and integrative analysis of large gene lists using DAVID bioinformatics resources. Nat Protoc. 2009;4:44-57.

22. Collier RJ, Dahl GE, Van Baale MJ. Major advances associated with environmental effects on dairy cattle. J Dairy Sci. 2006;89:1244-53. 
23. Bernabucci U, Biffani S, Buggiotti L, Vitali A, Lacetera N, Nardone A. The effects of heat stress in Italian Holstein dairy cattle. J Dairy Sci. 2014;97(1):471-86.

24. Alves BG, Alves KA, Lúcio AC, Martins MC, Silva TH, Alves BG, et al. Ovarian activity and oocyte quality associated with the biochemical profile of serum and follicular fluid from Girolando dairy cows postpartum. Anim Reprod Sci. 2014;146:117-25.

25. Liu T, Zhu S, Tang Q, Chen P, Yu Y, Tang S. De novo assembly and characterization of transcriptome using Illumina paired-end sequencing and identification of CesAgene in ramie (Boehmeria niveaL.Gaud). BMC Genomics. 2013;14:125

26. Voronina E, Lovasco LA, Gyuris A, Baumgartner RA, Parlow AF, Freiman RN. Ovarian granulosa cell survival and proliferation requires the gonadselective TFIID subunit TAF4b. Dev Biolv. 2007;303(2):715-26.

27. Heads RJ, Yellon DM, Latchman DS. Differential cytoprotection against heat stress or hypoxia following expression of specific stress protein genes in myogenic cells. J Mol Cell Cardiol. 1995;27(8):1669-78.

28. Iwazawa M, Acosta TJ. Effect of elevated temperatures on bovine corpus luteum function: expression of heat-shock protein 70, cell viability and production of progesterone and prostaglandins by cultured luteal cells. Anim Prod Sci. 2014;54:285-91.

29. Agnew LA, Colditz IG. Development of a method of measuring cellular stress in cattle and sheep. Vet Immuno Immunopathol. 2008;123:197-204.

30. Dangi SS, Gupta M, Maurya D, Yadav VP, Panda RP, Singh G. Expression profile of HSP genes during different seasons in goats (Capra hircus). Trop Anim Health Prod. 2012;44(8):1905-12.

31. Guerriero V Jr, Raynes DA. Synthesis of heat stress proteins in lymphocytes from livestock. J Anim Sci. 1990:68:2779-83.

32. Malayer JR, Hansen PJ, Buhi WC. Effect of day of the oestrous cycle, side of the reproductive tract and heat shock on in-vitro protein secretion by bovine endometrium. J Reprod Fertil. 1988;84(2):567-78.

33. Putney DJ, Malayer JR, Gross TS, Thatcher WW, Hansen PI, Drost M. Heat stress-induced alterations in the synthesis and secretion of proteins and prostaglandins by cultured bovine conceptuses and uterine endometrium. Biol Reprod. 1988;39:717-28.

34. Harada T, Koi H, Kubota T, Aso T. Haem oxygenase augments porcine granulosa cell apoptosis in vitro. J Endocrinol. 2004;181(1):191-205.

35. Mishra A, Hooda OK, Singh G, Meur SK. Influence of induced heat stress on HSP70 in buffalo lymphocytes. J Anim Physiol Anim Nutr. 2011;95(4):540-4.

36. Beck SC, Paidas CN, Tan H, Yang J, De MA. Depressed expression of the inducible form of HSP70 (HSP 72) in brain and heart after in vivo heat shock. Am J Phys. 1995;269:R608-13.

37. Albers R, Bol M, Seinen W, Pieters R. Stress proteins (HSP) and chemicalinduced autoimmunity. Toxicol Appl Pharmacol. 1996;140:70-6.

38. Meza-Herreraab CA, Martíneza L, Aréchigac C, Bañuelosc R, Rincónc RM, Urrutiab J. Circannual identification and quantification of constitutive heat shock proteins (HSP 70) in goats. J App Anim Res. 2005;29(1):9-12.

39. Hayashi Y, Iwai T, Toshio K, Tatsuya K, Kenzo O. Translocation of hsp-70 and protein synthesis during continuous heating at mild temperatures in HeLa cells. Radiat Res. 1991;125:1.

40. Kim D, Virginia W, Somji S, Garrett SH, Sens MA, Shukla D. Expression of hsp 27 , hsp 60, hsc 70, and hsp 70 by immortalized human proximal tubule cells (hk-2) following exposure to heat shock, sodium arsenite, or cadmium chloride. J Toxicol Environ Health A. 2001;63(7):475-93.

41. Dehbi M, Baturcam E, Eldali A, Ahmed M, Kwaasi A, Chishti MA. Hsp-72, a candidate prognostic indicator of heatstroke. Cell Stress Chaperones. 2010;15:593-603.

42. Ferencz A, Juhasz R, Butnariu M, Deer AK, Varga IS, Nemcsok J. Expression analysis of heat shock genes in the skin, spleen and blood of common carp (Cyprinuscarpio) after cadmium exposure and hypothermia. Acta Biol Hung. 2010;63(1):15-25.

43. Givisiez PE, Ferro JA, Ferro MI, Kronka SN, Decuypere E, Macari M. Hepatic concentration of heat shock protein $70 \mathrm{kD}(\mathrm{Hsp} 70)$ in broilers subjected to different thermal treatments. Br Poult Sci. 1999;40:292-6.

44. Hernandes R, Ferro JA, Gonzales E, Macari M, Bernal FEM, Ferro MIT. Resistance to ascites syndrome, homoeothermic competence and levels of Hsp70 in the heart and lung of broilers. Revistabrasileira de zootecniabrazilian. J Anim Sci. 2002;31:1442-50.

45. Zulkifli I, Omar AR, Sazili AQ, Rajion MA. Crating and heat stress influence blood parameters and heat shock protein 70 expression in broiler chickens showing short or long tonic immobility reactions. Anim Welf. 2003;88:1-6.
46. Taylor P, Zulkifli I, Norma MTC, Israf DA, Omar AR. The effect of early-age food restriction on heat shock protein 70 response in heat-stressed female broiler chickens. Br Poult Sci. 2010;43:141-5.

47. Wang S, Edens FW. Stress-induced heat-shock protein synthesis in peripheral leukocytes of turkeys, meleagris gallopavo. Comp Biochem Physiol. 1993;106(3):621-8.

48. Lewis S, Handy RD, Cordi UB, Billinghurst Z, Depledge MH. Stress proteins (HSP's): methods of detection and their use as an environmental biomarker. Ecotoxicology. 2000;8(5):351-68.

49. Mosser DD, Caron AW, Bourget L, Meriin AB, Sherman MY, Morimoto RI. The chaperone function of hsp70 is required for protection against stressinduced apoptosis. Mol Cell Biol. 2000;20(19):7146-59.

50. Stankiewicz AR, Lachapelle G, Foo CP, Radicioni SM, Mosser DD. Hsp70 inhibits heat-induced apoptosis upstream of mitochondria by preventing Bax translocation. J Biol Chem. 2005;280(46):38729-39.

51. Lee $J M$, Kim KR, Im H, Kim YH. Zinc preconditioning protects against neuronal apoptosis through the mitogen-activated protein kinase-mediated induction of heat shock protein 70. Biochem Biophys Res Commun. 2015; 459(2):220-6

52. Azad MAK, Kikusato M, Sudo S, Amo T, Toyomizu M. Time course of ROS production in skeletal muscle mitochondria from chronic heatexposed broiler chicken. Comp Biochem Physiol A Mol Integr Physiol. 2010;157(3):266-71.

53. Gu ZT, Li L, Wu F, Zhao P, Yang H, Liu YS. Heat stress induced apoptosis is triggered by transcription-independent p53, $\mathrm{Ca}(2+)$ dyshomeostasis and the subsequent Bax mitochondrial translocation. Sci Rep. 2015;5:11497.

54. Guerin P, El-Mouatassim S, Menezo Y. Oxidative stress and protection against reactive oxygen species in the pre-implantation embryo and its surroundings. Hum Reprod. 2001;7(2):175-89.

55. Fu Y, He CJ, Ji PY, Zhuo ZY, Tian XZ, Wang F. Effects of melatonin on the proliferation and apoptosis of sheep granulosa cells under thermal stress. Int J Mol Sci. 2014;15(11):21090-104.

56. Cabello CM, Bair WB, Lamore SD, Ley S, Bause AS, Azimian S. The cinnamonderived Michael acceptor Cinnamic aldehyde impairs melanoma cell proliferation, invasiveness, and tumor growth. Free Rad Biol Med. 2009;46(2):220-31.

57. Wu KC, McDonald PR, Liu JJ, Chaguturu R, Klaassen CD. Implementation of a high-throughput screen for identifying small molecules to activate the Keap1-Nrf2-ARE pathway. PLoS One. 2012;7(10):e44686.

58. Alemu TW, Hari OP, Dessie SW, Samuel G, Christiane N, Ernst T, et al. Oxidative and endoplasmic reticulum stress defense mechanisms of bovine granulosa cells exposed to heat stress. Theriogenology. 2017;12:042.

59. Alcendor RR, Gao S, Zhai P, Zablocki D, Holle E, Yu X, et al. Sirt1 regulates aging and resistance to oxidative stress in the heart. Circ Res. 2007;100(15):12-1521.

60. Fernando WGD, Ramarathnam R, Krishnamoorthy AS, Savchuk S. Identification and use of bacterial organic volatiles in biological control of Sclerotiniasclerotiorum. Soil Biol Biochem. 2005;37:955-64.

61. Vesco DAP, Gasparino E. Production of reactive oxygen species, gene expression, and enzymatic activity in quail subjected to acute heat stress. J Anim Sci. 2013;91:582-7.

62. Wolfenson D, Lew BJ, Thatcher WW, Graber Y, Meidan R. Seasonal and acute heat stress effects on steroid production by dominant follicles in cows. Anim Reprod Sci. 1997;47(1-2):9-19.

63. Mendelson CR, Jiang B, Shelton JM, Richardson JA, Hinshelwood MM. Transcriptional regulation of aromatase in placenta and ovary. J Steroid Biochem Mol Biol. 2005;95:25-33.

64. Mosa A, Neunzig J, Gerber A, Zapp J, Hannemann F, Pilak P, et al. 2 $\beta$ and $16 \beta$-hydroxylase activity of CYP11A1 and direct stimulatory effect of estrogens on pregnenolone formation. J Steroid Biochem Mol Biol. 2015;150:1-10.

65. Zhang JY, Wu Y, Zhao S, Liu ZX, Zeng SM, Zhang GX. Lysosomes are involved in induction of steroidogenic acute regulatory protein (StAR) gene expression and progesterone synthesis through low-density lipoprotein in cultured bovine granulosa cells. Theriogenology. 2015;284(5):811-7.

66. Rekawiecki R, Nowik M, Kotwica J. Stimulatory effect of LH, PGE2 and progesterone on StAR protein, cytochrome P450 cholesterol side chain cleavage and 3 beta hydroxysteroid dehydrogenase gene expression in bovine luteal cells. Prostaglandins Other Lipid Mediat. 2005;78:169-84.

67. Sirotkin AV, Bauer M. Heat shock proteins in porcine ovary: synthesis, accumulation and regulation by stress and hormones. Cell Stress Chaperones. 2011;16(4):379-87. 
68. Shimizu T, Ohshima I, Ozawa M, Takahashi S, Tajima A, Shiota M, et al. Heat stress diminishes gonadotropin receptor expression and enhances susceptibility to apoptosis of rat granulosa cells. Reproduction. 2005;129(4):463-72.

69. Saibil H. Chaperone machines for protein folding, unfolding and disaggregation. Nature reviews Mol Cell Biol. 2013;14(10):630-42.

70. Livak KJ, Schmittgen TDF. Analysis of relative gene expression data using real-time quantitative PCR and the 2(-Delta Delta C(T)) method. Methods (San Diego Calif). 2001;25(4):402-8.

Ready to submit your research? Choose BMC and benefit from:

- fast, convenient online submission

- thorough peer review by experienced researchers in your field

- rapid publication on acceptance

- support for research data, including large and complex data types

- gold Open Access which fosters wider collaboration and increased citations

- maximum visibility for your research: over $100 \mathrm{M}$ website views per year

At $B M C$, research is always in progress.

Learn more biomedcentral.com/submissions 